Article

\title{
Optimal Earthquake Intensity Measures for Probabilistic Seismic Demand Models of Base-Isolated Nuclear Power Plant Structures
}

\author{
Duy-Duan Nguyen $^{1}\left(\mathbb{D}\right.$, Tae-Hyung Lee ${ }^{2, *}$ and Van-Tien Phan ${ }^{1}$ \\ 1 Department of Civil Engineering, Vinh University, Vinh 461010, Vietnam; duan468@gmail.com (D.-D.N.); \\ vantien.phan1010@gmail.com (V.-T.P.) \\ 2 Department of Civil \& Environmental Engineering, Konkuk University, Seoul 05029, Korea \\ * Correspondence: thlee@konkuk.ac.kr
}

check for updates

Citation: Nguyen, D.-D.; Lee, T.-H.; Phan, V.-T. Optimal Earthquake Intensity Measures for Probabilistic Seismic Demand Models of Base-Isolated Nuclear Power Plant Structures. Energies 2021, 14, 5163. https://doi.org/10.3390/en14165163

Academic Editor: Guglielmo Lomonaco

Received: 19 July 2021

Accepted: 18 August 2021

Published: 20 August 2021

Publisher's Note: MDPI stays neutral with regard to jurisdictional claims in published maps and institutional affiliations.

Copyright: (C) 2021 by the authors. Licensee MDPI, Basel, Switzerland. This article is an open access article distributed under the terms and conditions of the Creative Commons Attribution (CC BY) license (https:/ / creativecommons.org/licenses/by/ $4.0 /)$.

\begin{abstract}
The purpose of this study is to evaluate the optimal earthquake intensity measures (IMs) for probabilistic seismic demand models (PSDMs) of the base-isolated nuclear power plant (NPP) structures. The numerical model of NPP structures is developed using a lumped-mass stick model, in which a bilinear model is employed to simulate the force-displacement relations of base isolators. In this study, 20 different IMs are considered and 90 ground motion records are used to perform time-history analyses. The seismic engineering demand parameters (EDPs) are monitored in terms of maximum floor displacement (MFD), the maximum floor acceleration (MFA) of the structures, and maximum isolator displacement (MID). As a result, a set of PSDMs of the base-isolated structure is developed based on three EDPs (i.e., MFD, MFA, and MID) associated with 20 IMs. Four statistical parameters including the coefficient of determination, efficiency (i.e., standard deviation), practicality, and proficiency are then calculated to evaluate optimal IMs for seismic performances of the isolated NPP structures. The results reveal that the optimal IMs for PSDMs with respect to MFD and MID are velocity spectrum intensity, Housner intensity, peak ground velocity, and spectral velocity at the fundamental period. Meanwhile, peak ground acceleration, acceleration spectrum intensity, A95, effective peak acceleration, and sustained maximum acceleration are efficient IMs for PSDMs with respect to MFA of the base-isolated structures. On the other hand, cumulative absolute velocity is not recommended for determining the exceedance of the operating basis earthquake of base-isolated NPP structures.
\end{abstract}

Keywords: nuclear power plant structure; earthquake intensity measure; lead rubber bearing; time-history analysis; probabilistic seismic demand model; optimality

\section{Introduction}

The existing seismic design codes commonly use peak ground acceleration (PGA) or spectral acceleration $\left(S_{a}\right)$ as the earthquake intensity measure (IM). Additionally, these IMs are commonly applied for the seismic performance evaluations of infrastructures. Numerous studies have been carried out to evaluate the correlation between ground motion IMs and the seismic responses of various civil engineering structures [1-10]. Those studies pointed out that PGA and $S_{a}$ are not always the optimal options for seismic performance evaluations and fragility analyses of civil engineering structures. Moreover, some studies concluded that velocity-based IMs are efficient for predicting seismic demand models of base-isolated buildings [11,12].

The seismic performance evaluation of infrastructures is commonly based on probabilistic approaches [13-15]. It is necessary to consider these methods for seismic risk assessments of nuclear structures [16]. For that, a probabilistic form of the engineering demand for significant IMs should be determined.

Generally, the nuclear engineering community has used a lumped-mass stick model (LMSM) or a full three-dimensional finite element model (3D FEM) to perform time-history 
analyses of nuclear power plant (NPP) structures [17]. Since 3D FEM always requires a very time-consuming computation, the simplified approach (i.e., LMSM) is still used widely. Many studies used LMSM to perform the seismic responses and fragility assessment of NPP structures and systems [18-22]. Moreover, the effects of different base isolators on the seismic performances and fragility analyses of NPP components were investigated using LMSM [23-31]. The benefits of isolators for improving the seismic responses of structures and systems were analyzed thoroughly. It is noted that those studies mostly employed PGA or $S_{a}$ as earthquake IMs for performing seismic structural analyses and evaluations.

Only a few studies have identified the correlation between the IMs and the seismic damage of NPP structures. Li et al. [32] analyzed the correlation between the IMs and the seismic damage of a Canada Deuterium Uranium (CANDU) containment structure. They pointed out that the spectral acceleration $\left(S_{a}\left(T_{1}\right)\right)$ and the spectral displacement at the fundamental period $\left(\mathrm{S}_{\mathrm{d}}\left(\mathrm{T}_{1}\right)\right)$ are the optimum IMs. Nguyen et al. [33] performed time-history analyses to recognize the strongly correlated IMs for non- and base-isolated NPP structures considering high-frequency ground motions. They demonstrated that the effects of high-frequency earthquakes on the calculated correlation coefficients are significant. Recently, Nguyen et al. [34] identified the optimal IMs for probabilistic seismic demand models of a non-isolated containment building. However, those IMs may not be efficient for base-isolated NPP structures. Tran et al. [35] developed probabilistic seismic demand models of cabinets in NPPs and generated fragility curves for this equipment considering high- and low-frequency earthquakes. Nevertheless, it is necessary to evaluate optimal earthquake IMs for seismic risk assessment of base-isolated NPP structures using probabilistic seismic demand models.

This study aims to identify optimal IMs to develop probabilistic seismic demand models (PSDMs) of based-isolated primary structures in the advanced power reactor 1400 MWe (APR1400) NPP. The numerical model of NPP structures is constructed using LMSM in SAP2000. A total of 20 earthquake IMs are considered in deriving PSDMs. A set of 90 ground motion records, which cover a wide range of amplitudes, magnitudes, epicentral distances, significant durations, and predominant periods, are utilized to perform nonlinear time-history analyses. Seismic engineering demand parameters (EDPs) are monitored in terms of maximum floor displacement (MFD), the maximum floor acceleration (MFA) of the structures, and maximum isolator displacement (MID). PSDMs of the base-isolated structure are then developed based on three EDPs associated with 20 IMs. Finally, optimal IMs are identified based on the four statistical properties of PSDMs, which are the coefficient of determination, efficiency (i.e., dispersion), practicality, and proficiency.

\section{Ground Motions}

\subsection{Earthquake Intensity Measures}

Earthquake IMs normally contain the fundamental characteristics of ground motions, such as amplitude, frequency content, and earthquake duration [36]. Over time, many IMs have been proposed to apply for the seismic designs and performance evaluations of specific structures. Some IMs represent the cumulative energy over the earthquake duration or the combination of the seismic motion property and the structural characteristic. This study considers 20 typical earthquake IMs, which are calculated for every motion record using the SeismoSignal software [37]. The investigated IMs are presented in Table 1.

\subsection{Input Ground Motions}

The minimum number of ground motion records is required in performing probabilistic seismic demand analyses [38] for proper consideration of uncertainties in earthquakes. A big enough number of ground motion records needs to be used where this number can be varied depending on the investigated structure, normally from 10 to 20 records [38]. In this study, a set of 90 ground motion records are selected from the PEER center database [39] and KMA [40] to cover a wide band of earthquake characteristics for establishing probabilistic seismic demand models. A wide range of earthquake amplitudes, magnitudes, 
epicentral distances, significant durations, and predominant periods is considered in the used ground motions. In particular, the set consists of 67 near-fault and 23 far-fault ground motions. The response spectra of 90 motion records are shown in Figure 1, in which the mean spectrum is matched with the US Nuclear Regulatory Commission (NRC) 1.60 design spectrum [41]. The statistical parameters of the selected ground motions are presented in Table 2.

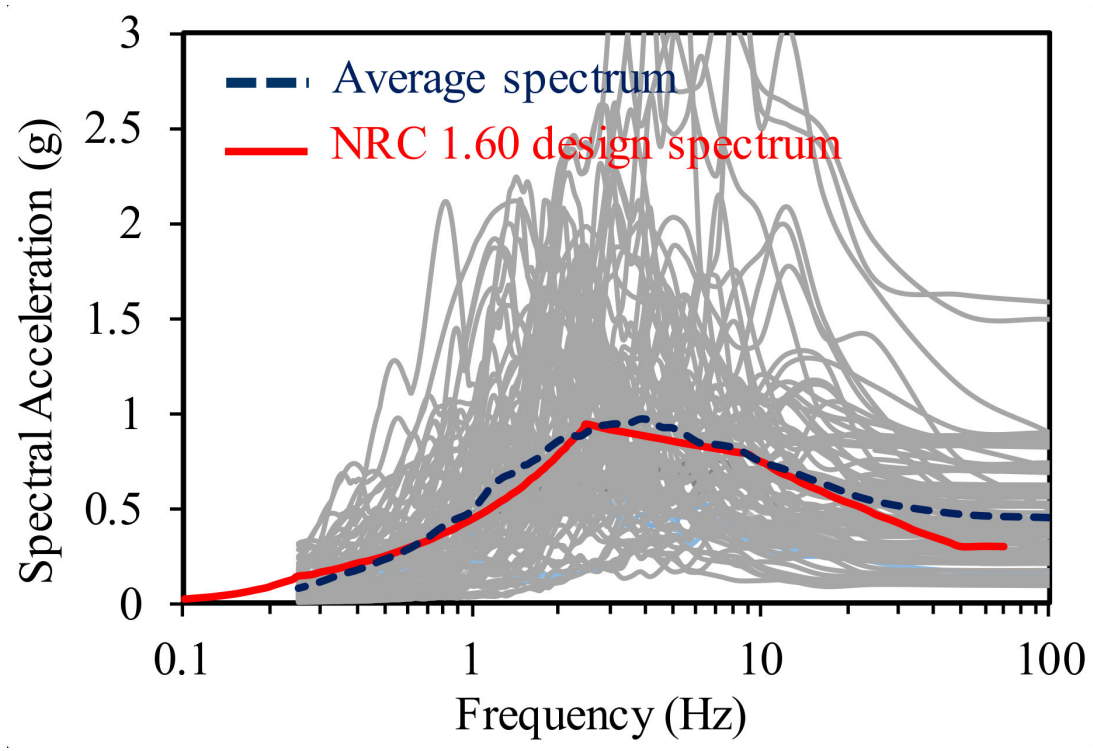

Figure 1. Response spectra of 90 ground motion records.

Table 1. Earthquake intensity measures.

\begin{tabular}{|c|c|c|c|c|}
\hline ID & Intensity Measure & Definition & Unit & Ref. \\
\hline 1 & Peak ground acceleration & $P G A=\max |a(t)|$ & $\mathrm{g}$ & - \\
\hline 2 & Peak ground velocity & $P G V=\max |v(t)|$ & $\mathrm{m} / \mathrm{s}$ & - \\
\hline 3 & Peak ground displacement & $P G D=\max |d(t)|$ & $\mathrm{m}$ & - \\
\hline 4 & Root-mean-square of acceleration & $A_{r m s}=\sqrt{\frac{1}{t_{t o t}} \int_{0}^{t_{\text {tot }}} a(t)^{2} d t}$ & $\mathrm{~g}$ & Dobry et al. [42] \\
\hline 5 & Root-mean-square of velocity & $V_{r m s}=\sqrt{\frac{1}{t_{\text {tot }}} \int_{0}^{t_{t o t}} v(t)^{2} d t}$ & $\mathrm{~m} / \mathrm{s}$ & Kramer [36] \\
\hline 6 & Root-mean-square of displacement & $D_{r m s}=\sqrt{\frac{1}{t_{\text {tot }}} \int_{0}^{t_{\text {tot }}} d(t)^{2} d t}$ & $\mathrm{~m}$ & Kramer [36] \\
\hline 7 & Arias intensity & $I_{a}=\frac{\pi}{2 g} \int_{0}^{t_{t o t}} a(t)^{2} d t$ & $\mathrm{~m} / \mathrm{s}$ & Arias [43] \\
\hline 8 & Characteristic intensity & $I_{c}=\left(A_{r m s}\right)^{3 / 2} \sqrt{t_{t o t}}$ & $\mathrm{~m}^{1.5} / \mathrm{s}^{2.5}$ & Park et al. [44] \\
\hline 9 & Specific energy density & $\mathrm{SED}=\int_{0}^{t_{t o t}} v(t)^{2} d t$ & $\mathrm{~m}^{2} / \mathrm{s}$ & - \\
\hline 10 & Cumulative absolute velocity & $\mathrm{CAV}=\int_{0}^{t_{t o t}}|a(t)| d t$ & $\mathrm{~m} / \mathrm{s}$ & Benjamin [45] \\
\hline 11 & Acceleration spectrum intensity & ASI $=\int_{01}^{0.5} S_{a}(\xi=0.05, T) d T$ & $g^{*} s$ & Thun et al. [46] \\
\hline 12 & Velocity spectrum intensity & $\mathrm{VSI}=\int_{0.1}^{2.5} S_{v}(\xi=0.05, T) d T$ & $\mathrm{~m}$ & Thun et al. [46] \\
\hline 13 & Housner spectrum intensity & $\mathrm{HI}=\int_{01}^{2.5} P S_{v}(\xi=0.05, T) d T$ & $\mathrm{~m}$ & Housner [47] \\
\hline 14 & Sustained maximum acceleration & $\mathrm{SMA}=$ the $3 \mathrm{rd}$ of PGA & $\mathrm{g}$ & Nuttli [48] \\
\hline 15 & Sustained maximum velocity & $S M V=$ the $3 r d$ of PGV & $\mathrm{m} / \mathrm{s}$ & Nuttli [48] \\
\hline 16 & Effective peak acceleration & $\mathrm{EPA}=\frac{\operatorname{mean}\left(S_{a}^{0.1-0.5}(\xi=0.05)\right)}{25}$ & g & Benjamin [45] \\
\hline 17 & Spectral acceleration at $T_{1}$ & $S_{a}\left(T_{1}\right)^{2.5}$ & $\begin{array}{l}0 \\
\mathrm{~g}\end{array}$ & Shome et al. [49] \\
\hline 18 & Spectral velocity at $T_{1}$ & $S_{v}\left(T_{1}\right)$ & $\mathrm{m} / \mathrm{s}$ & - \\
\hline 19 & Spectral displacement at $\mathrm{T}_{1}$ & $S_{d}\left(T_{1}\right)$ & $\mathrm{m}$ & - \\
\hline 20 & A95 parameter & $A_{95}=0.764 I_{a}^{0.438}$ & $\mathrm{~g}$ & Sarma \& Yang [50] \\
\hline
\end{tabular}


Table 2. Statistical properties of selected ground motions.

\begin{tabular}{cccccc}
\hline Parameters & Min. & Max. & Mean & $\begin{array}{c}\text { Standard } \\
\text { Deviation }\end{array}$ & $\begin{array}{c}\text { Coefficient of } \\
\text { Variation }\end{array}$ \\
\hline PGA (g) & 0.093 & 1.585 & 0.453 & 0.272 & 0.601 \\
PGA/PGV & 0.250 & 3.294 & 1.088 & 0.614 & 0.565 \\
Magnitude, $M_{w}$ & 5.2 & 7.8 & 6.63 & 0.513 & 0.077 \\
$\begin{array}{c}\text { Epicentral distance, } \\
R(\mathrm{~km})\end{array}$ & 0.07 & 89.76 & 12.23 & 14.027 & 1.14 \\
$\begin{array}{c}\text { Significant duration, } \\
D_{5-95}(\mathrm{~s})\end{array}$ & 2.79 & 60.77 & 11.934 & 9.034 & 0.757 \\
$\begin{array}{c}\text { Predominant } \\
\text { period, } T_{p}(\mathrm{~s})\end{array}$ & 0.04 & 1.24 & 0.374 & 0.202 & 0.540 \\
\hline
\end{tabular}

\section{Numerical Modeling of Base-Isolated APR1400 NPP Structures}

The primary structures in APR1400 NPPs are employed to develop the numerical model including a reactor containment building $(\mathrm{RCB})$, a reactor containment internal structure (IS), and an auxiliary building (AB). Figure 2a shows a cutting view of the NPP structures. LMSM is utilized to construct the finite element model of the structures in SAP2000 [51], a commercial finite element analysis program, as shown in Figure 2b. The containment and auxiliary buildings are modeled in terms of elastic beam elements with concentrated masses at the nodes. The structural properties of beam elements are determined based on the dimensions and cross-sectional details of the structures [52]. The shell elements are applied for modeling the base-mat foundation. The structural properties of the APR1400 structures in LMSM are provided in Tables 3-5.

Table 3. Structural properties of the rector containment building (RCB) in LMSM.

\begin{tabular}{ccccccc}
\hline Node & $\begin{array}{c}\text { Height from } \\
\text { Base-Mat }(\mathbf{m})\end{array}$ & $\begin{array}{c}\text { Nodal Mass } \\
(\mathbf{t o n})\end{array}$ & $\begin{array}{c}\text { Area } \\
\left(\mathbf{m}^{\mathbf{2}}\right)\end{array}$ & $\begin{array}{c}\text { Moment of Inertia } \\
\left(\mathbf{m}^{\mathbf{4}}\right)\end{array}$ & $\begin{array}{c}\text { Shear Area } \\
\left(\mathbf{m}^{\mathbf{2}}\right)\end{array}$ & $\begin{array}{c}\text { Torsional } \\
\text { Constant }\end{array}$ \\
\hline 1 & 16.76 & 87.07 & 202.90 & $56,299.85,56,299.85$ & 101.45 & $112,634.22$ \\
2 & 20.27 & 166.52 & 202.90 & $56,299.85,56,299.85$ & 101.45 & $112,634.22$ \\
3 & 23.46 & 185.42 & 202.90 & $56,299.85,56,299.85$ & 101.45 & $112,634.22$ \\
4 & 27.73 & 189.29 & 202.90 & $56,299.85,56,299.85$ & 101.45 & $112,634.22$ \\
5 & 31.09 & 170.39 & 202.90 & $56,299.85,56,299.85$ & 101.45 & $112,634.22$ \\
6 & 34.59 & 234.68 & 202.90 & $56,299.85,56,299.85$ & 101.45 & $112,634.22$ \\
7 & 40.53 & 314.15 & 202.90 & $56,299.85,56,299.85$ & 101.45 & $112,634.22$ \\
8 & 47.24 & 333.05 & 202.90 & $56,299.85,56,299.85$ & 101.45 & $112,634.22$ \\
9 & 53.94 & 318.02 & 202.90 & $56,299.85,56,299.85$ & 101.45 & $112,634.22$ \\
10 & 60.65 & 310.43 & 202.90 & $56,299.85,56,299.85$ & 101.45 & $112,634.22$ \\
11 & 66.44 & 376.80 & 202.90 & $56,299.85,56,299.85$ & 101.45 & $112,634.22$ \\
12 & 70.56 & 279.92 & 179.76 & $47,591.20,47,591.20$ & 89.89 & $95,199.65$ \\
13 & 78.63 & 355.52 & 179.76 & $35,861.70,35,861.70$ & 89.89 & $71,732.03$ \\
14 & 86.72 & 352.09 & 166.11 & $12,825.63,12,825.63$ & 83.03 & $25,651.25$ \\
\hline
\end{tabular}




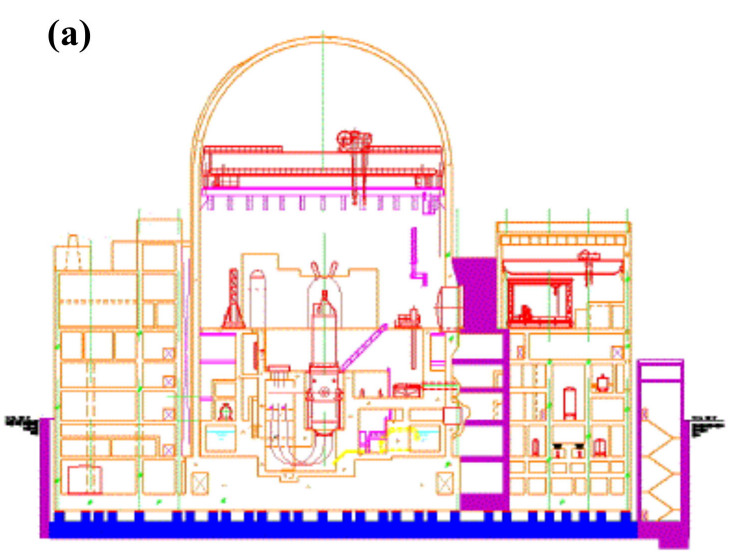

(c)
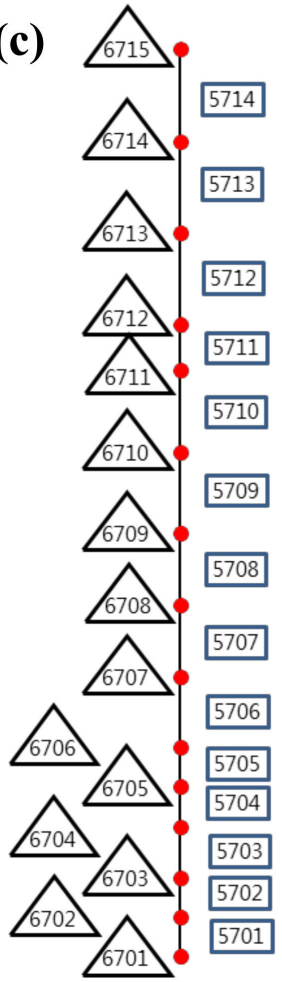

(d)

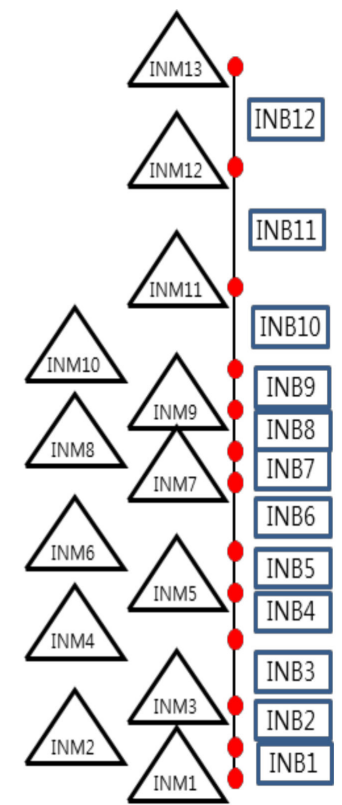

(b)

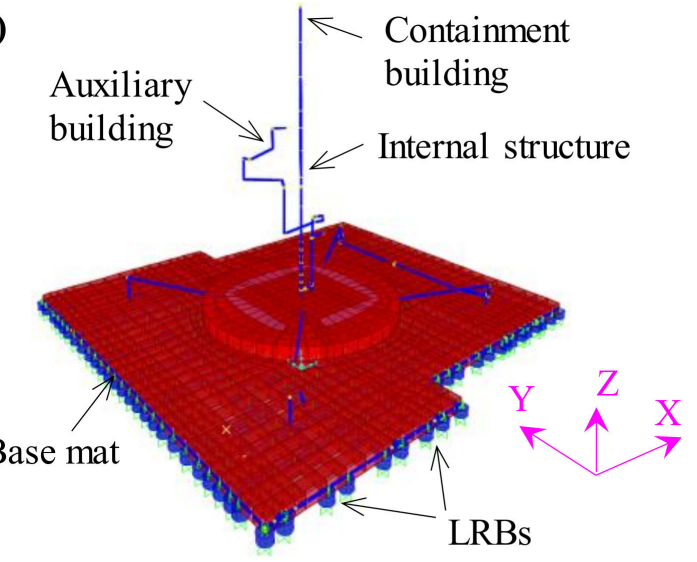

(e)

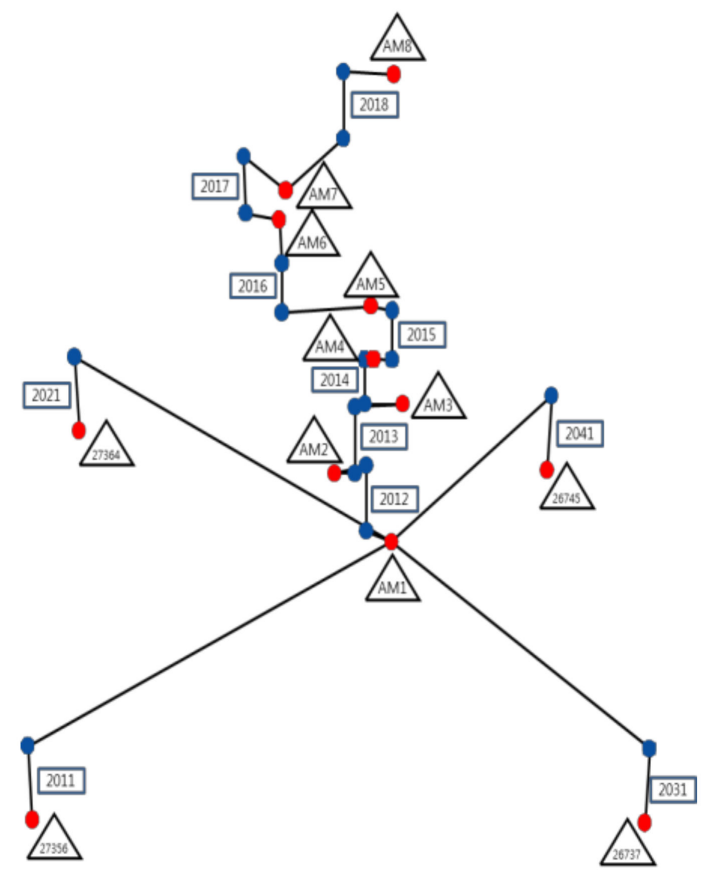

Figure 2. Base-isolated APR1400 NPP structures; (a) elevation view and (b) finite element model, (c) lumped-mass stick model of RCB, (d) lumped-mass stick model of IS, and (e) lumped-mass stick model of AB (Note: triangles are for nodes and rectangles are for elements).

A total of 486 LRBs are installed under the base mat for enhancing the seismic performance of the structures. Figure 3 shows the layout of LRBs and the bilinear response model of the isolator under shear forces. The mechanical properties of LRBs are described in Table 6. The results of the natural frequencies and corresponding mode shapes are shown in Table 7 and Figure 4, respectively. It can be observed that the first three modes are governed by base isolators. The first and second modes are translation $\mathrm{Y}$ and $\mathrm{X}$, respectively, of the superstructure; meanwhile, the third mode is the rotation of the structure about the $\mathrm{Z}$-axis. The fourth mode is the translation of the containment building. This observation is also consistent with the previous studies [53,54]. 
Table 4. Structural properties of the rector containment internal structure (IS) in LMSM.

\begin{tabular}{|c|c|c|c|c|c|c|}
\hline Node & $\begin{array}{l}\text { Height from } \\
\text { Base-Mat (m) }\end{array}$ & $\begin{array}{l}\text { Nodal Mass } \\
\text { (ton) }\end{array}$ & $\begin{array}{l}\text { Area } \\
\left(\mathrm{m}^{2}\right)\end{array}$ & $\begin{array}{c}\text { Moment of Inertia } \\
\left(\mathrm{m}^{4}\right)\end{array}$ & $\begin{array}{c}\text { Shear Area } \\
\qquad\left(\mathrm{m}^{2}\right)\end{array}$ & $\begin{array}{c}\text { Torsional } \\
\text { Constant }\left(\mathrm{m}^{4}\right)\end{array}$ \\
\hline 1201 & 16.76 & 184.17 & 833.15 & $51,055.67,79,896.93$ & 662.77 & $164,989.72$ \\
\hline 1202 & 18.28 & 341.40 & 883.97 & $51,262.81,81,942.48$ & 704.29 & $168,389.13$ \\
\hline 1203 & 20.26 & 796.48 & 857.92 & $51,149.25,80,710.1$ & 684.03 & $165,957.82$ \\
\hline 1204 & 23.46 & 523.67 & 313.78 & $9908.34,21,253.36$ & 221.77 & $37,753.43$ \\
\hline 1204 & 25.75 & 273.10 & 254.60 & $9816.63,19,442.95$ & 171.14 & $35,811.75$ \\
\hline 1205 & 27.73 & 296.29 & 221.94 & $9515.25,19,384.02$ & 144.33 & $35,233.94$ \\
\hline 1206 & 31.09 & 296.86 & 261.38 & $9848.14,20,166.32$ & 175.93 & $36,571.27$ \\
\hline 1207 & 32.61 & 355.47 & 202.76 & $9630.81,18,524.13$ & 130.81 & $34,566.87$ \\
\hline 1208 & 34.59 & 80.51 & 202.76 & $9630.81,18,524.13$ & 130.81 & $34,566.87$ \\
\hline 1209 & 36.57 & 264.64 & 202.76 & $9630.81,18,524.13$ & 130.75 & $34,566.87$ \\
\hline 1210 & 40.53 & 255.68 & 103.23 & $1932.60,4666.70$ & 94.90 & 7888.57 \\
\hline 1211 & 46.32 & 271.76 & 97.93 & $1918.14,4642.60$ & 92.25 & 7840.37 \\
\hline
\end{tabular}

Table 5. Structural properties of the auxiliary building (AB) in LMSM.

\begin{tabular}{ccccccc}
\hline Node & $\begin{array}{c}\text { Height from } \\
\text { Base-Mat }(\mathbf{m})\end{array}$ & $\begin{array}{c}\text { Nodal Mass } \\
\mathbf{( t o n )}\end{array}$ & $\begin{array}{c}\text { Area } \\
\left(\mathbf{m}^{\mathbf{2}}\right)\end{array}$ & $\begin{array}{c}\text { Moment of Inertia } \\
\mathbf{( m}^{\mathbf{4}} \mathbf{)}\end{array}$ & $\begin{array}{c}\text { Shear Area } \\
\left(\mathbf{m}^{\mathbf{2}} \mathbf{)}\right.\end{array}$ & $\begin{array}{c}\text { Torsional } \\
\mathbf{C o n s t a n t}\left(\mathbf{m}^{\mathbf{4}}\right)\end{array}$ \\
\hline 1001 & 16.76 & 4608.78 & 1660.45 & $530,766.3,405,355.4$ & $770.35,611.30$ & $239,729.53$ \\
1002 & 23.46 & 5265.66 & 1503.17 & $466,685.8,332,679.3$ & $658.91,582.41$ & $198,363.83$ \\
1003 & 36.57 & 4680.11 & 1529.65 & $464,101.2,340,852.6$ & $659.42,589.37$ & $205,791.05$ \\
1004 & 41.91 & 4150.72 & 1363.35 & $368,330.8,292,325.7$ & $565.41,558.81$ & $187,226.65$ \\
1005 & 40.53 & 3218.83 & 842.16 & $241,060.5,158,771.4$ & $358.88,329.06$ & $173,747.81$ \\
1006 & 52.42 & 2000.28 & 579.06 & $142,392.3,121,479.2$ & $212.0,261.6$ & $76,553.8$ \\
1007 & 57.92 & 1659.49 & 371.98 & $75,850.4,86,362.9$ & $160.3,192.0$ & $52,753.99$ \\
1008 & 63.39 & 957.38 & & & & \\
\hline
\end{tabular}

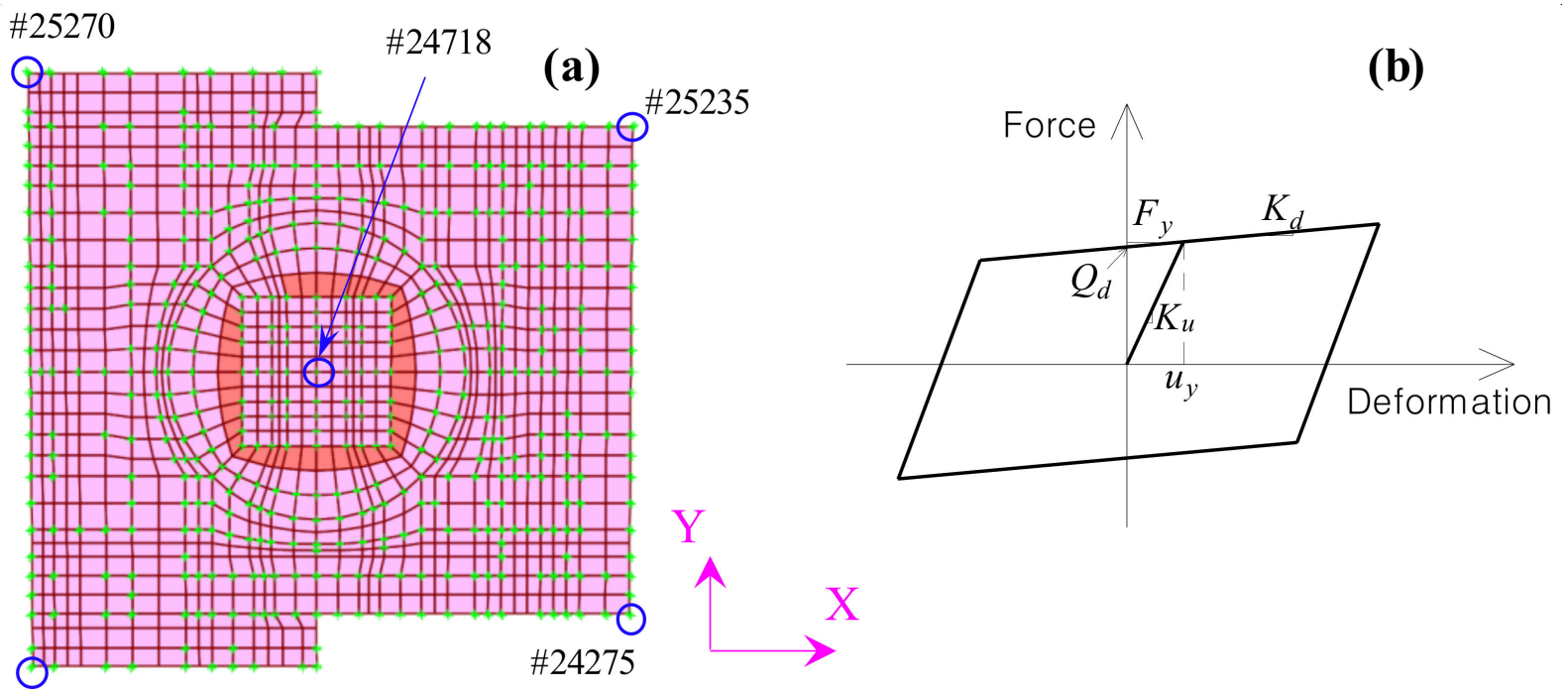

\#24189

Figure 3. LRB arrangement (a) and bilinear force-deformation behavior of LRBs (b). 
Table 6. Mechanical properties of base isolators.

\begin{tabular}{ccc}
\hline Property & Value & Unit \\
\hline Elastic stiffness, $K_{u}$ & 544.70 & $\mathrm{kN} / \mathrm{mm}$ \\
Hardening stiffness, $K_{d}$ & 4.20 & $\mathrm{kN} / \mathrm{mm}$ \\
Yield strength, $F_{y}$ & 1009.65 & $\mathrm{kN}$ \\
Characteristic strength, $Q_{d}$ & 1001.03 & $\mathrm{kN}$ \\
Vertical stiffness, $K_{v}$ & 12.896 & $\mathrm{kN} / \mathrm{mm}$ \\
Effective stiffness, $K_{\text {eff }}$ & 8.97 & $\mathrm{kN} / \mathrm{mm}$ \\
Equivalent damping ratio, $\xi$ & 0.335 & \\
\hline
\end{tabular}

Table 7. Eigenvalue analysis results.

\begin{tabular}{ccc}
\hline Mode & Natural Frequency $\mathbf{( H z )}$ & Description \\
\hline Mode 1 & 0.477 & Translational Y of superstructure \\
Mode 2 & 0.477 & Translational X of superstructure \\
Mode 3 & 0.709 & Rotational Z of superstructure \\
Mode 4 & 3.786 & Translational Y of RCB \\
\hline
\end{tabular}

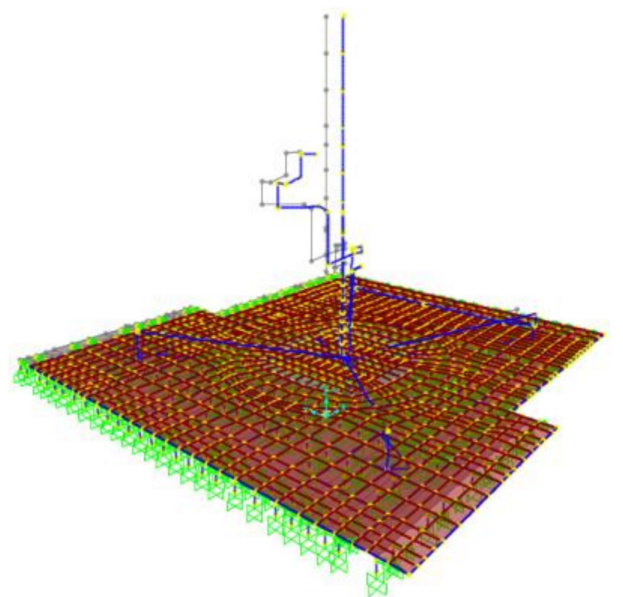

Mode 1 (Y translation of superstructure)

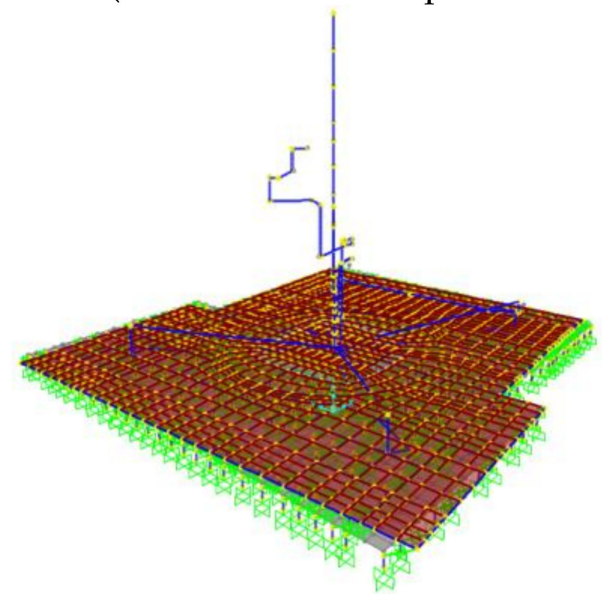

Mode 3 ( $Z$ rotation of superstructure)

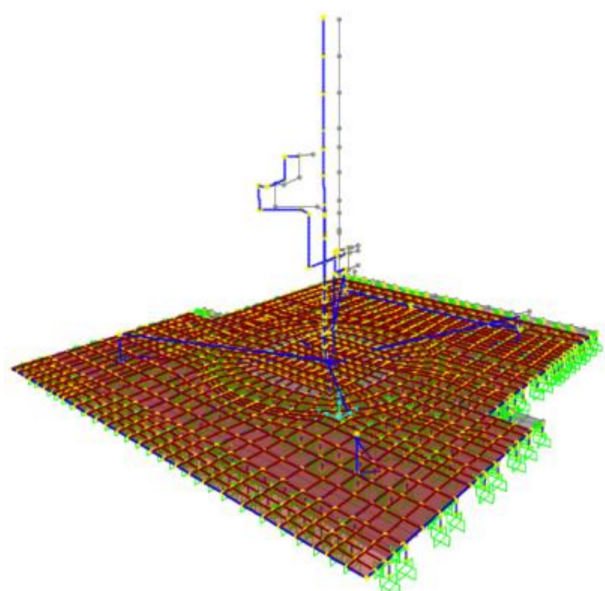

Mode 2 (X translation of superstructure)

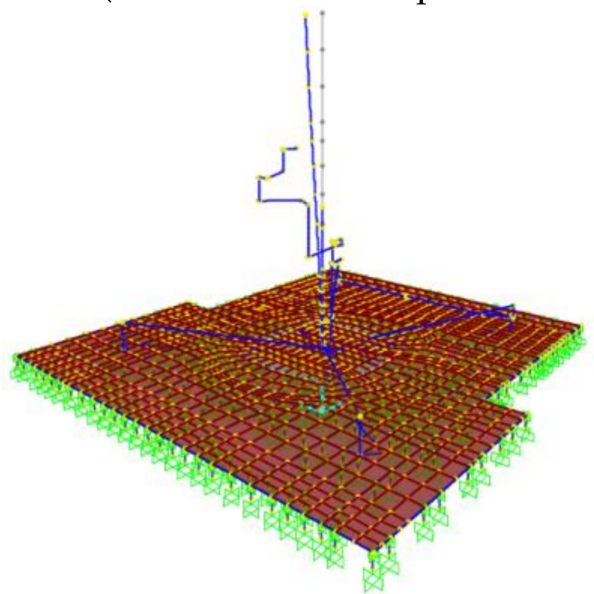

Mode 4 (Y translation of RCB)

Figure 4. The first four mode shapes. 


\section{Seismic Performance of Isolated NPP Structures}

Nonlinear time-history analyses are performed to quantify the seismic responses of based-isolated NPP structures. The following three engineering demand parameters (EDPs) are considered in this study:

- Maximum floor displacement (MFD), i.e., the maximum absolute value of the lateral floor displacement of the structures. MFD is an EDP correlated to the global stability of the structures.

- Maximum floor acceleration (MFA), i.e., the maximum absolute value of the floor acceleration of all the stories.

- Maximum isolator displacement (MID), i.e., an EDP to evaluate the damage of the base isolator.

Figures 5 and 6 show examples of displacement and acceleration time-history responses at the top of containment buildings under earthquakes, respectively. Since the earthquake energy is dissipated through the nonlinear behavior of LRBs, the responses of superstructures are governed by the performance of base isolators, in which the floor accelerations of structures are significantly reduced [55-58]. Figure 7 shows the hysteretic responses of the LBRs subjected to different ground motions. Some experimental studies [59-62] pointed out that the LRB can obtain a maximum deformation capacity of $400 \%$ shear strain. The shear strain is determined by the ratio $\Delta / H$, where $\Delta$ and $H$ are the maximum deformation and the height of LRB, respectively. In this study, the peak shear deformation of LBRs under 90 motions is $517 \mathrm{~mm}$, i.e., approximately $250 \%$ shear strain, which is obviously within the capacity of the bearing.
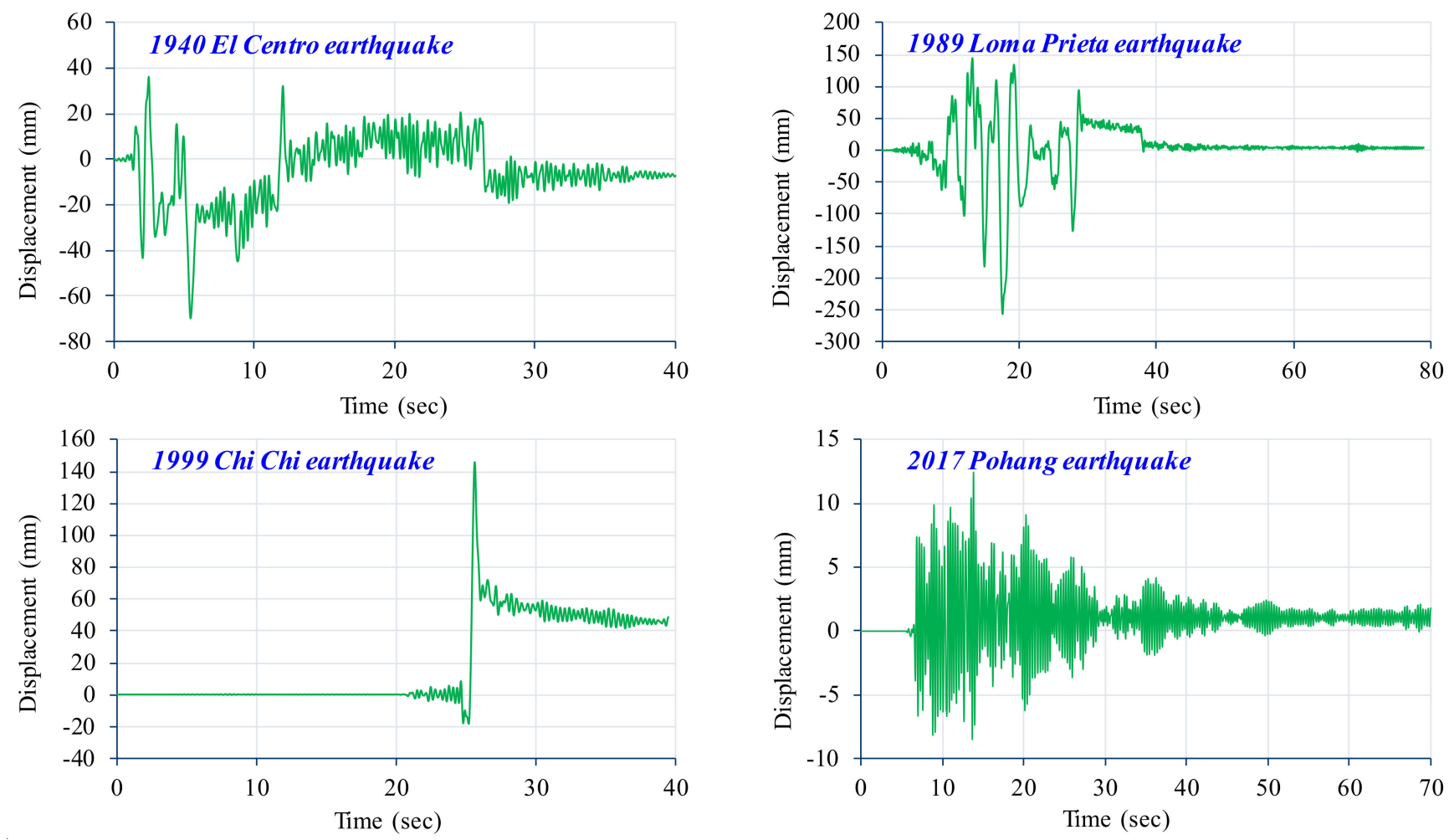

Figure 5. Displacement responses at the top of RCB under earthquakes. 

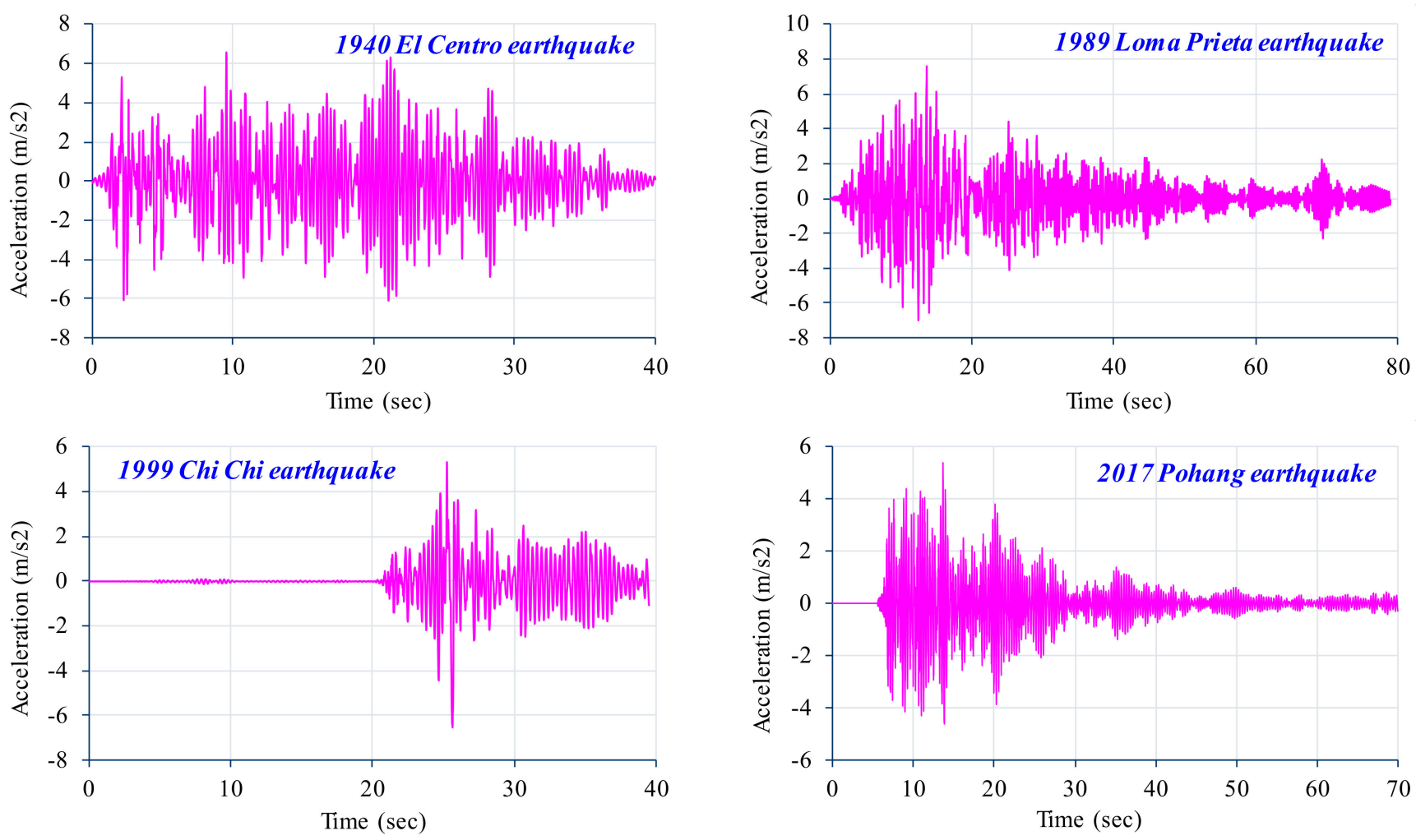

Figure 6. Acceleration responses at the top of RCB under earthquakes.
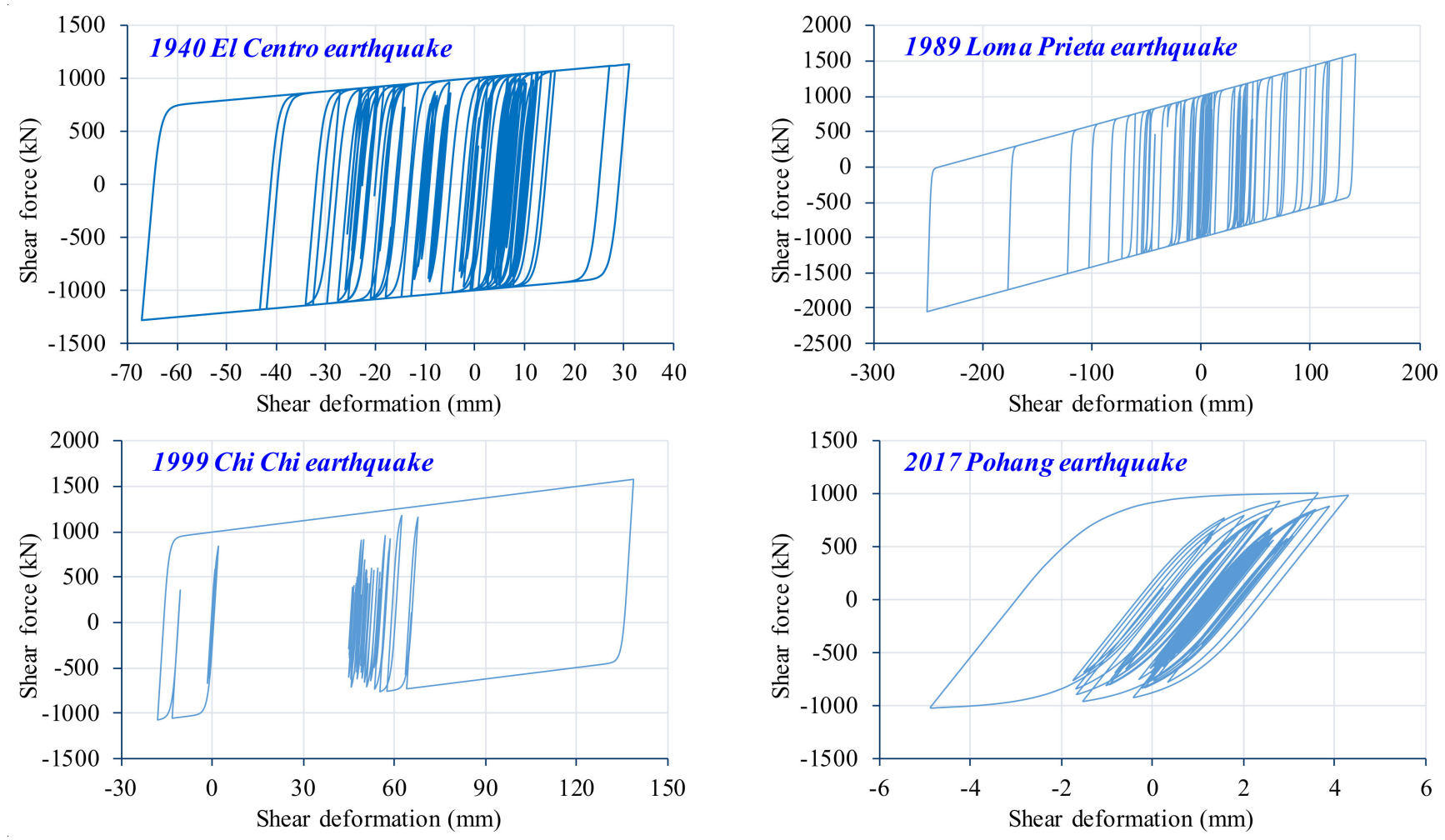

Figure 7. Nonlinear response of LRBs under different earthquakes. 


\section{Optimal Earthquake IMs for PSDM of Base-Isolated NPP Structures}

\subsection{Probabilistic Seismic Demand Model}

A PSDM represents the relationship between structural demand and an earthquake $I M$. This approach is necessary in establishing the probabilistic performance-based seismic design. The power function is the most common expression to determine the relationship between seismic demand and earthquake IMs, as shown in Equation (1).

$$
S_{D}=a \times(I M)^{b}
$$

where $S_{D}$ is the median value of structural demand; $a$ and $b$ are the regression coefficients; and the $I M$ is the earthquake intensity measure considered. This equation can be rewritten in forms of linear regression as follows:

$$
\ln \left(S_{D}\right)=\ln (a)+b \times \ln (I M)
$$

The conditional failure probability that the structural demand $(D)$ exceeds its capacity for a given IM in the fragility analysis can be expressed as follows:

$$
P_{f}=P[D \geq d \mid I M]
$$

where $d$ is the specified value; normally, it is based on the structural capacity. Assuming that the structural demand and capacity follow lognormal distributions, Equation (3) can be rewritten as follows:

$$
P[D \geq d \mid I M]=1-\Phi\left[\frac{\ln (d)-\ln \left(S_{D}\right)}{\sigma_{D \mid I M}}\right]
$$

where $\Phi[-]$ is the standard normal function and $\sigma_{D \mid I M}$ is the logarithmic standard deviation.

\subsection{Parameters for Evaluation of IMs}

In this study, four statistical parameters, namely, the coefficient of determination, efficiency, practicality, and proficiency, are used for evaluating the regression models and then identifying optimal IMs. These parameters have been widely utilized in the seismic risk evaluation of civil engineering structures [63]. Each indicator is described in this section.

\subsubsection{Coefficient of Determination $\left(R^{2}\right)$}

The coefficient of determination, $R^{2}$, provides the proportion of the variance of one variable that can be predicted from the other variable. For the PSDMs, the $R^{2}$ value denotes the percentage of the data that is the closest to the regression line (i.e., the best fit line). The closer the $R^{2}$ value is to unity, the more significant the regression model is. It can be calculated by the following:

$$
R^{2}=\left(\frac{n\left(\sum x_{i} y_{i}\right)-\left(\sum x_{i}\right)\left(\sum y_{i}\right)}{\sqrt{\left[n \sqrt{x_{i}^{2}}-\left(\sum x_{i}\right)^{2}\right]\left[n \sqrt{y_{i}^{2}}-\left(\sum y_{i}\right)^{2}\right]}}\right)^{2}
$$

where $n$ is the number of analysis data, and $x_{i}$ and $y_{i}$ are the results of the IMs and structural demand data, respectively.

\subsubsection{Efficiency (i.e., Standard Deviation)}

The efficiency indicator is evaluated by the dispersion of regression fit for engineering demand parameters and each IM. In other words, the efficiency is measured in terms of the 
standard deviation of the scatterings of the PSDM, referred as $\sigma_{D \mid I M}$. The less scattered the data are, the more efficient the IM is. The equation for calculating the efficiency value can be expressed as follows:

$$
\sigma_{\mathrm{D} \mid \mathrm{IM}}=\sqrt{\frac{\sum\left(\ln \left(d_{i}\right)-\ln \left(a \times I M^{b}\right)\right)^{2}}{n-2}}
$$

\subsubsection{Practicality}

The practicality represents the correlation between an IM and EDPs. This property is quantified using the regression model parameter, $b$ (i.e., the slope of the regression line), as described in Equation (2). The lower the value of $b$ is, the less practical the IM is.

\subsubsection{Proficiency}

The proficiency, proposed by Padgett et al. [3], is a parameter that balances the selection between the efficiency and practicality. The proficiency is defined by the ratio of dispersion $\left(\sigma_{D \mid I M}\right)$ to the practicality $(b)$, as shown in Equation (7). The smaller the proficiency is, the more proficient the PDSM is.

$$
\xi=\frac{\sigma_{D \mid I M}}{b}
$$

\subsection{Results and Discussions}

Three EDPs of the isolated structure (i.e., MRD, MFA, and MID) are obtained based on a series of time-history analyses using the 90 ground motions. Then, PSDMs are developed for all the considered IMs and EDPs. The optimality of the IMs is evaluated using four mentioned statistical indicators of PSDMs (coefficient of determination, efficiency, practicality, and proficiency). The higher the $R^{2}$ and practicality are, the more optimal the $\mathrm{IM}$ is. Meanwhile, if the efficiency (i.e., standard deviation) and proficiency are lower, the considered IM is more optimum and vice versa.

Figures 8 and 9 show PSDMs with respect to MFD and the ranking of statistical indicators of the regression models for various IMs, respectively. It can be observed that PSDMs with respect to VSI, HI, and PGV have the highest $R^{2}$ value and the lowest standard deviation and proficiency, followed by $\mathrm{S}_{\mathrm{V}}\left(\mathrm{T}_{1}\right), \mathrm{SMV}$, and $\mathrm{V}_{\mathrm{RMS}}$. In other words, the scattering of PSDMs using these IMs is much smaller than that of others. Even though the practicality of a PSDM for $\mathrm{A}_{\mathrm{RMS}}$ is shown to be the largest, velocity-based IMs including VSI, PGV, SMV, and HI also have a higher practicality value than that of other IMs. Overall, the strongly correlated IMs are directly related to the velocity of ground motions and response spectra at the fundamental period of the structure. It can be attributed to the reason that the isolator displacement is predominantly affected by the velocity of low- or intermediate-frequency earthquakes [64]. Accordingly, the earthquake velocity is strongly correlated to the displacement of the isolated NPP structure, which has low natural frequencies at the fundamental modes. This finding is also in line with the conclusions of the previous studies [11,12]. Moreover, the response spectra at the fundamental period, which combine the ground motion and structure characteristics, are relatively efficient for seismic performances of base-isolated NPP structures. It is also important to highlight that the well-known criterion for determining the exceedance of the operating basis earthquake of NPPs [65], CAV, has a low correlation with the response of base-isolated NPP structures. On the other hand, Figure 8 indicates that the inefficient IMs for the PSDMs of the isolated structure are $\mathrm{D}_{\mathrm{RMS}}, \mathrm{ASI}, \mathrm{SMA}$, and PGD. It should be noted that the observed results presented in Figures 8 and 9 are for the RCB structure; however, the resulting trend of IS and $A B$ are very similar to those of $R C B$, therefore, we show the typical result here for sake of space. 

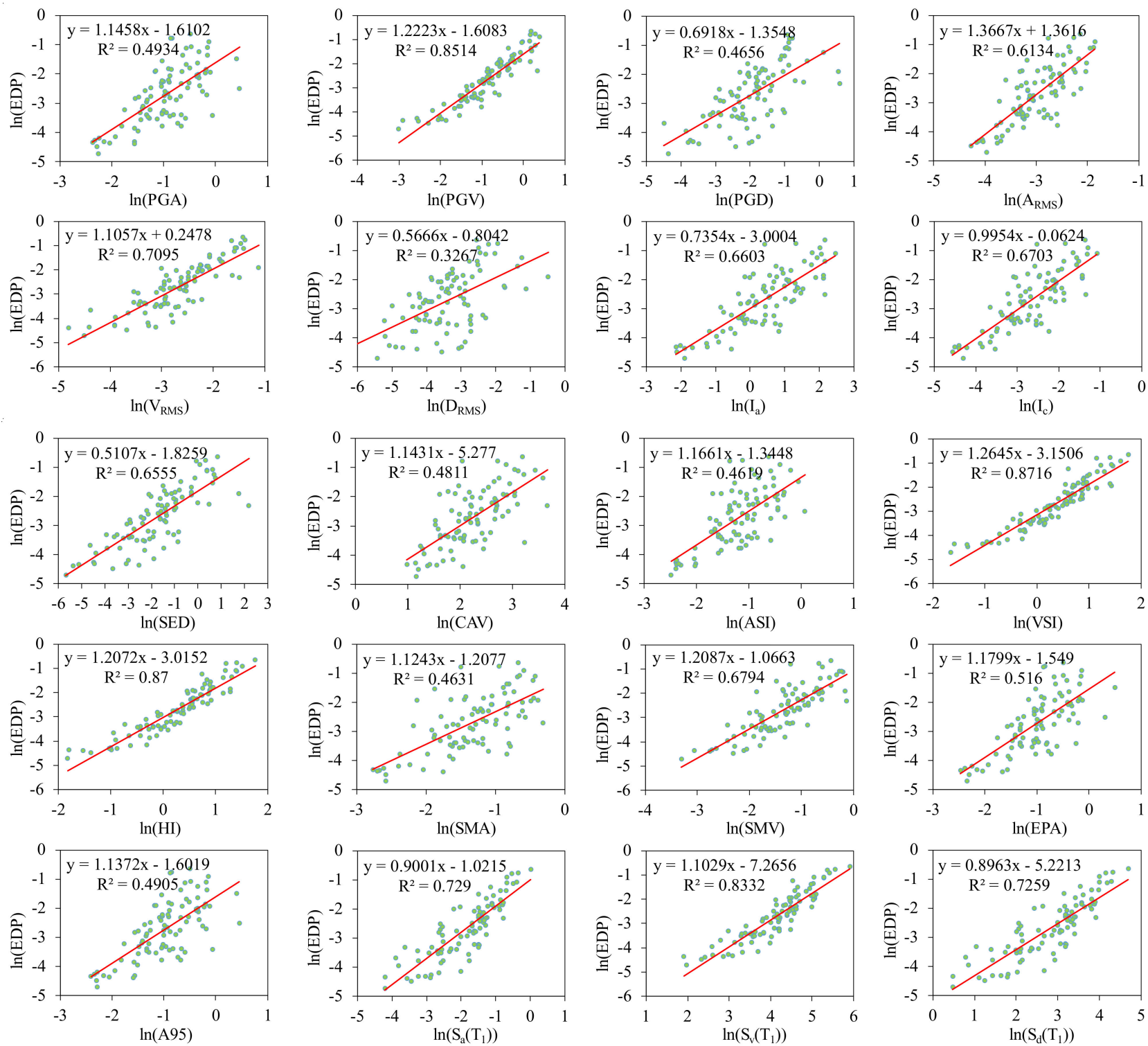

Figure 8. PSDMs with respect to MFD of RCB for various IMs.

Figure 10 shows PSDMs with respect to MFA of the NPP structure, in which PGA, A95, EPA, and ASI have the largest $R^{2}$ value, followed by SMA, $I_{C}, A_{R M S}$, and $I_{a}$. These IMs are related to the acceleration of earthquakes. Figure 11 shows the ranking of four statistical parameters of the regression models for 20 IMs. It can be found that PSDMs in respect of PGA, ASI, A95, EPA, and SMA have the highest $R^{2}$ value and practicality, and the lowest standard deviation and proficiency compared to those for other IMs. In other words, these IMs are optimal in performing the PSDMs of base-isolated NPP structures. Moreover, $D_{R M S}, P G D, S_{d}\left(T_{1}\right)$, and SED are not appropriate for conducting seismic performance evaluations of isolated NPP structures. 


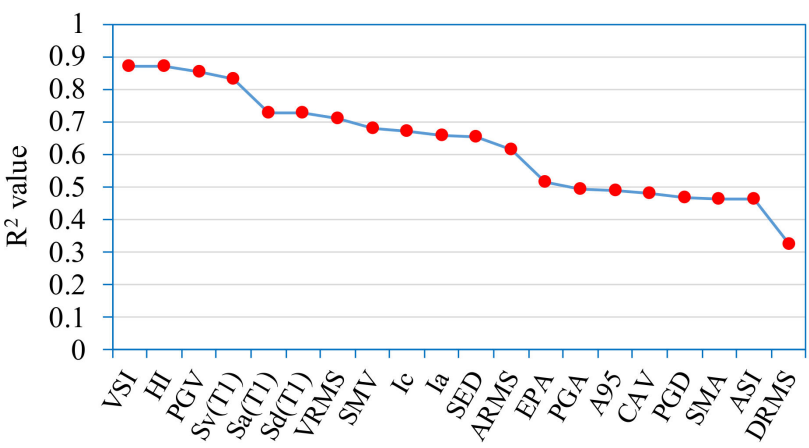

Intensity measure

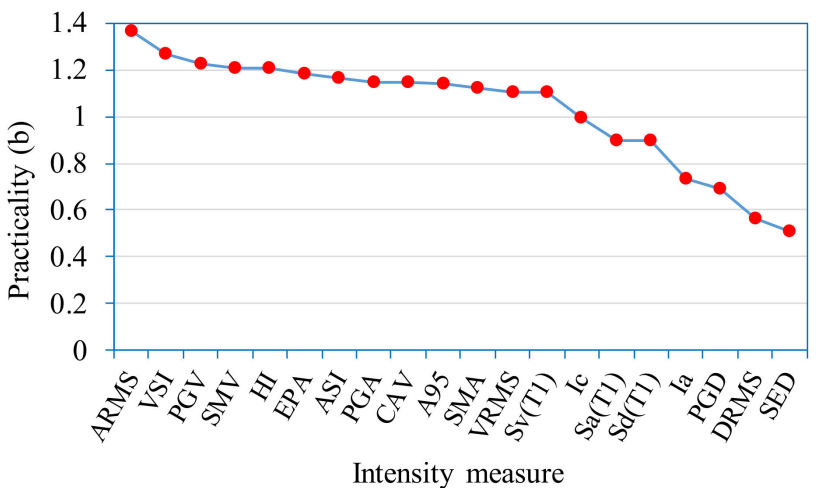

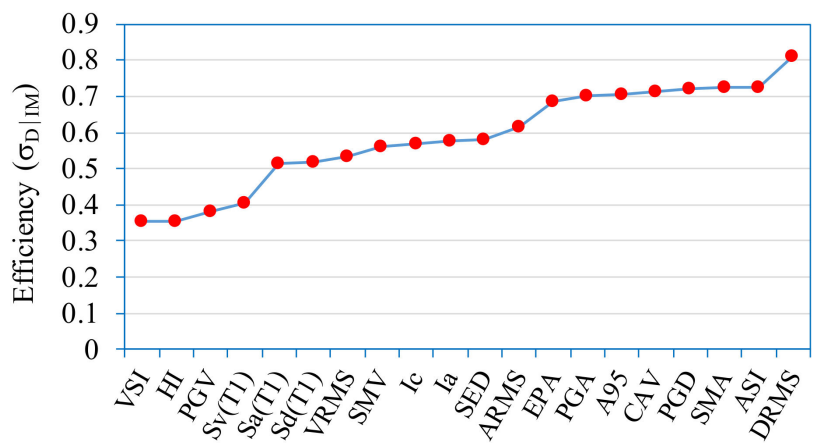

Intensity measure

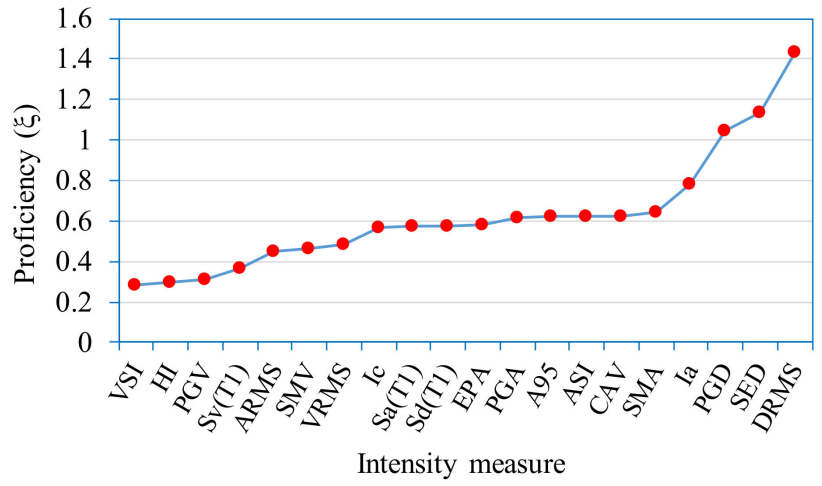

Figure 9. Ranking of indicators of PSDMs with respect to MFD for various IMs.

Figures 12 and 13 show PSDMs with respect to MID and the ordering of statistical indicators of the regression models for various IMs, respectively. It can be observed that PSDMs with respect to VSI, HI, PGV, and $\mathrm{S}_{\mathrm{V}}\left(\mathrm{T}_{1}\right)$ have a higher $R^{2}$ value and lower standard deviation and proficiency than those for other IMs. This observation is similar to that of PSDMs for the MFD of the structure showed in Figure 9. Although the practicality of PSDM for $A_{R M S}$ is shown to be the largest, velocity-based IMs, including VSI, PGV, and SMV, also have high practicality values. The reason can be attributed to the fact that the isolator displacement is dictated by the velocity of low- or intermediate-frequency ground motions. Furthermore, $\mathrm{D}_{\mathrm{RMS}}, \mathrm{PGD}$, and SED are not suitable for seismic performance evaluations of isolated NPP structures.

\section{Conclusions}

This study developed probabilistic seismic demand models (PSDMs) and evaluated the optimal earthquake intensity measures (IMs) for seismic performances of base-isolated nuclear power plant (NPP) structures. LMSM was used to construct the numerical model of the isolated APR1400 NPP structures. A total of 20 IMs and 90 ground motion records were employed to perform nonlinear time-history analyses. Seismic engineering demand parameters (EDPs) were monitored in terms of maximum floor displacement (MFD), the maximum floor acceleration (MFA) of the structures, and maximum isolator displacement (MID). As result, a set of PSDMs of the base-isolated structure were developed based on three EDPs (i.e., MFD, MFA, and MID) associated with 20 IMs. The following conclusions are drawn.

- The optimal IMs for PSDMs with respect to MFD and MID are VSI, HI, PGV, and $\mathrm{S}_{\mathrm{V}}\left(\mathrm{T}_{1}\right)$. Meanwhile, $\mathrm{D}_{\mathrm{RMS}}, \mathrm{ASI}, \mathrm{SMA}$, and PGD are inappropriate IMs for the PSDMs of isolated NPP structures.

- $\quad$ PGA, ASI, A95, EPA, and SMA are efficient IMs for PSDMs with respect to the MFA of the base-isolated structures, whereas $\mathrm{D}_{\mathrm{RMS}}, \mathrm{PGD}, \mathrm{S}_{\mathrm{d}}\left(\mathrm{T}_{1}\right)$, and SED are not appropriate for conducting seismic performance evaluations of isolated NPP structures. 
- $\quad \mathrm{CAV}$ is not recommended for determining the exceedance of the operating basis earthquake of base-isolated NPP structures.

- The findings in this study can be applied for the probabilistic seismic risk assessment of base-isolated NPP structures.

- It should be noted that the analysis will be much more demanding for other types of reactors such as IV Gen reactors because of different designs of whole NPP due to the specific features of the reactor (e.g., mass of lead in case of LFR or lower structural integrity of HTR graphite blocks) [66,67].
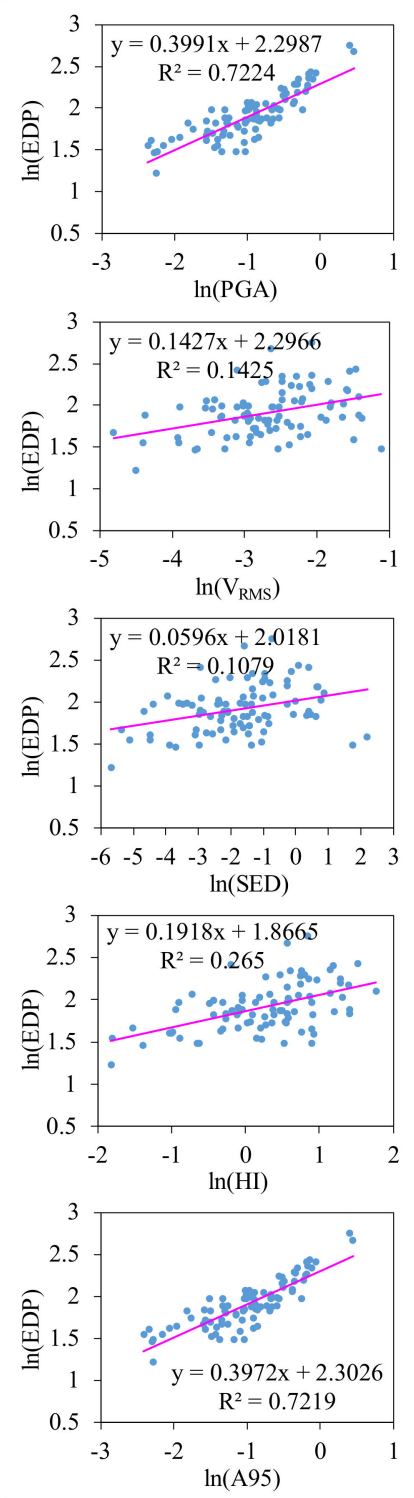
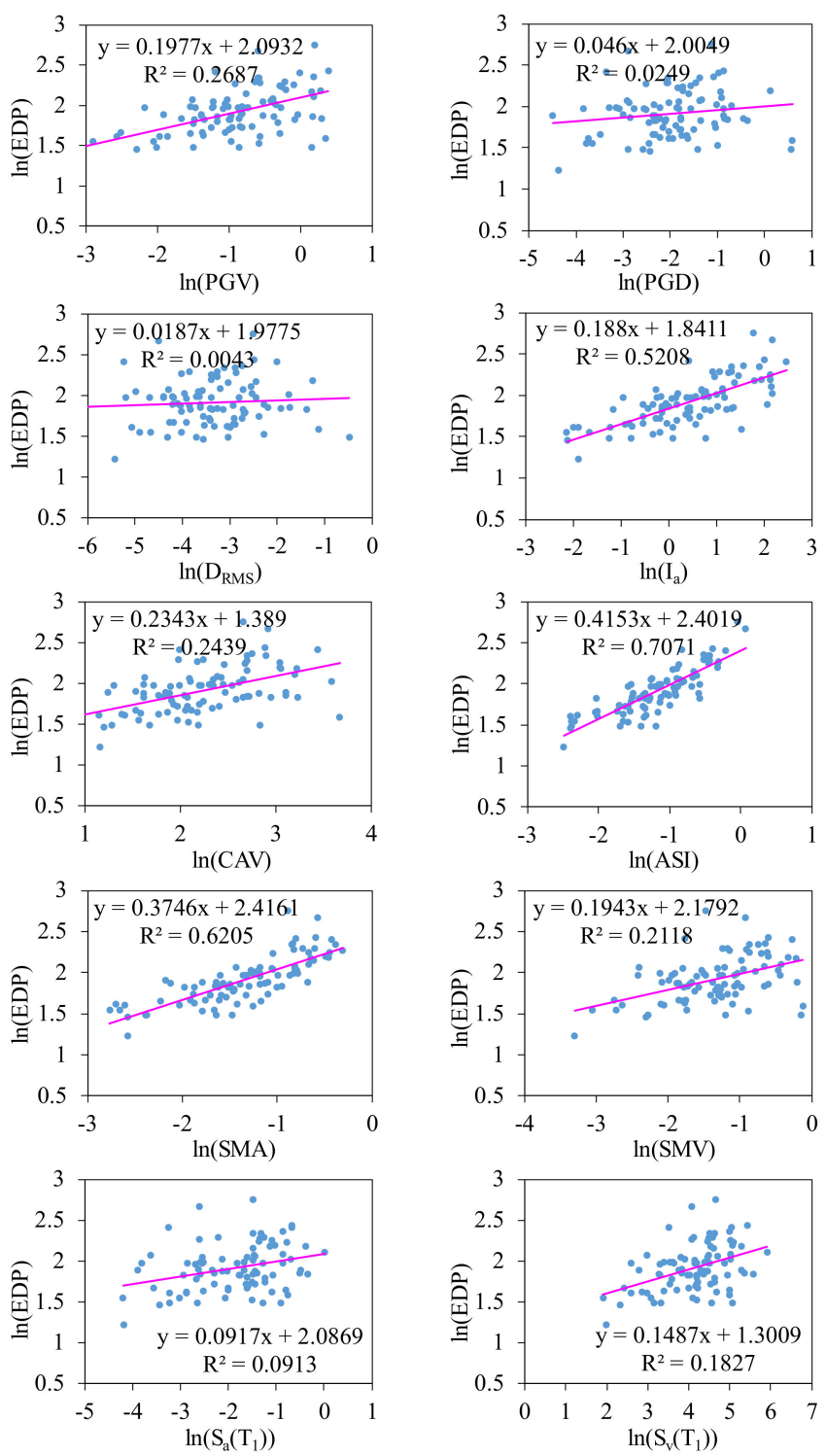
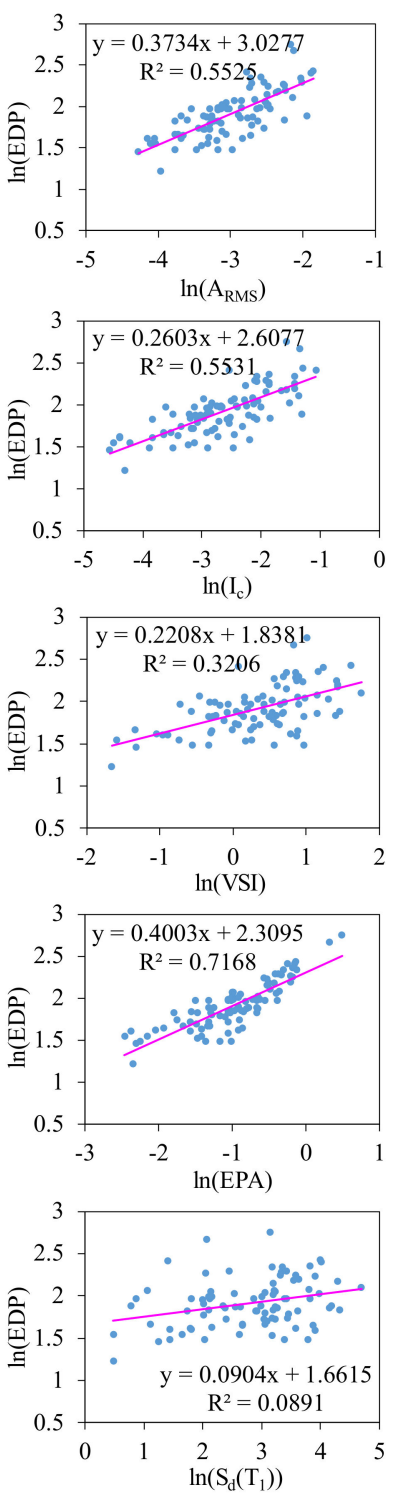

Figure 10. PSDMs with respect to MFA of RCB for various IMs. 


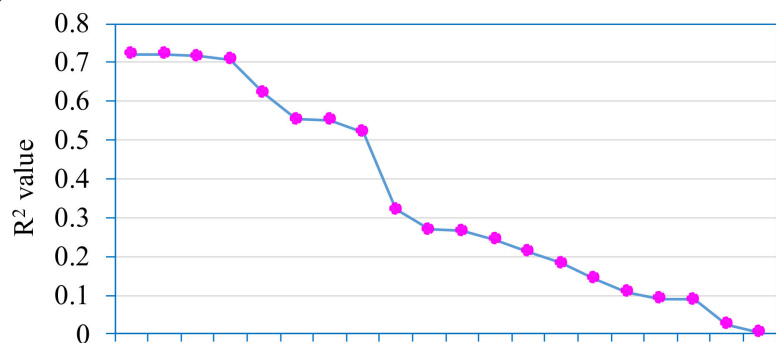

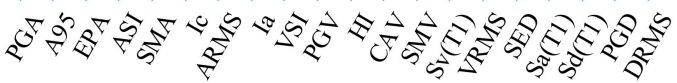

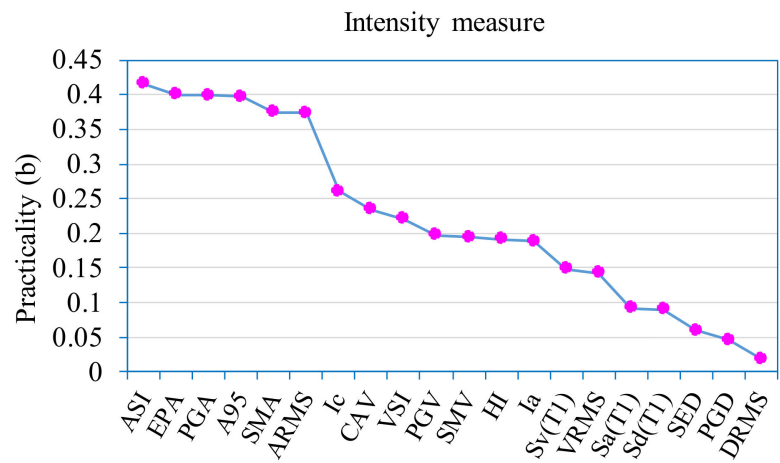

Intensity measure

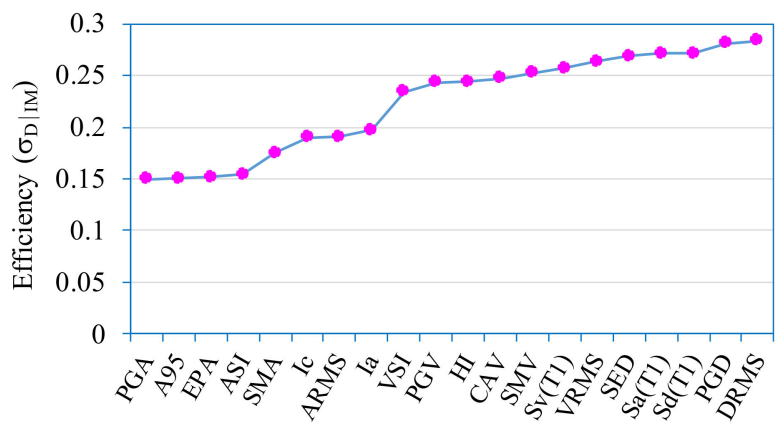

Intensity measure

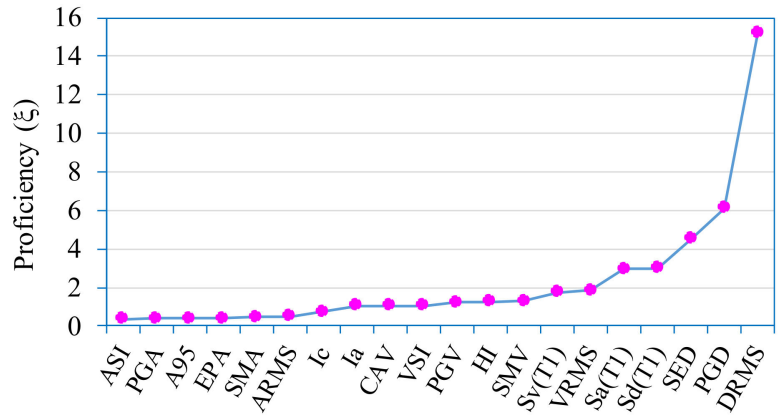

Intensity measure

Figure 11. Ranking of indicators of PSDMs with respect to MFA for various IMs.
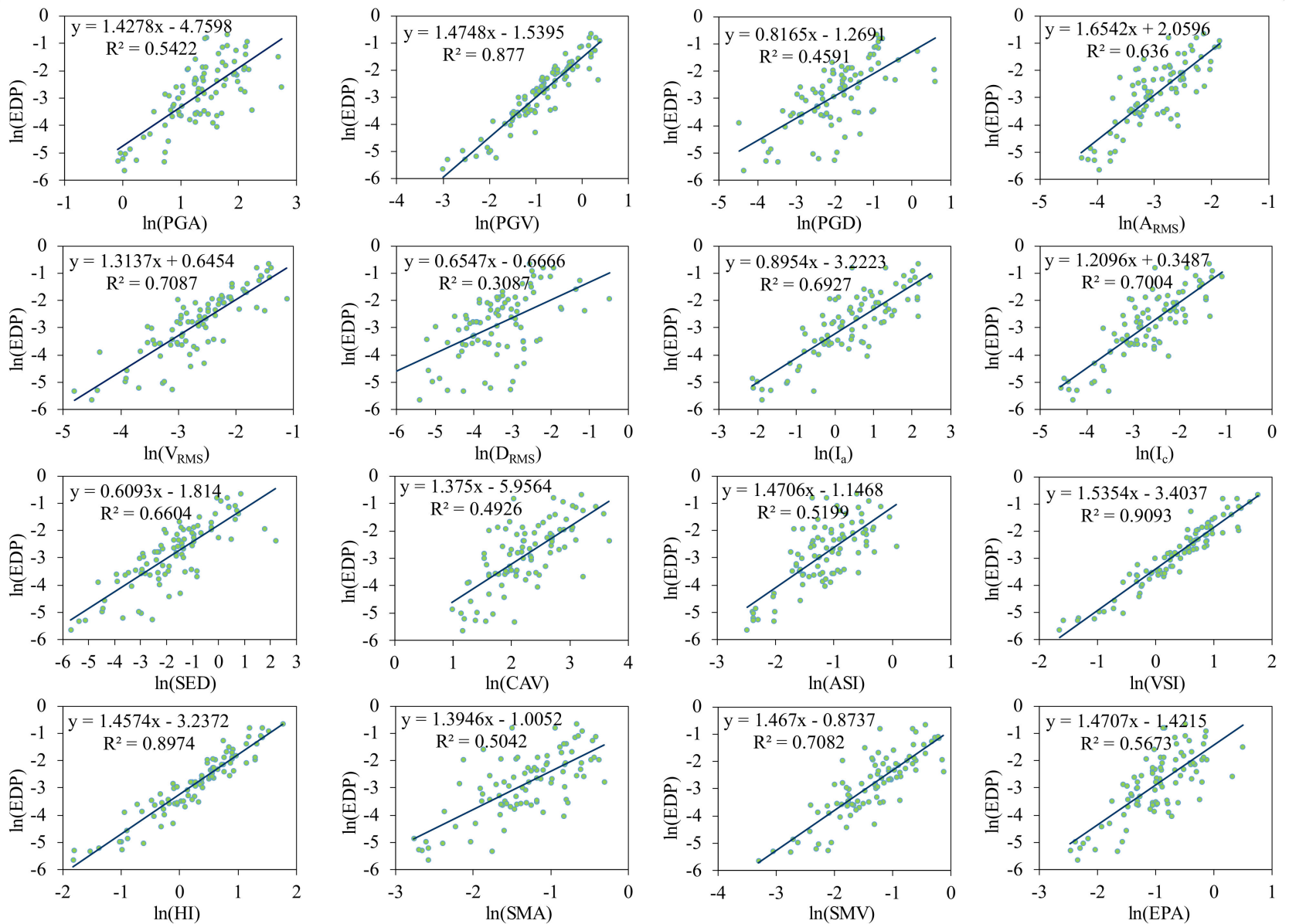

Figure 12. Cont. 

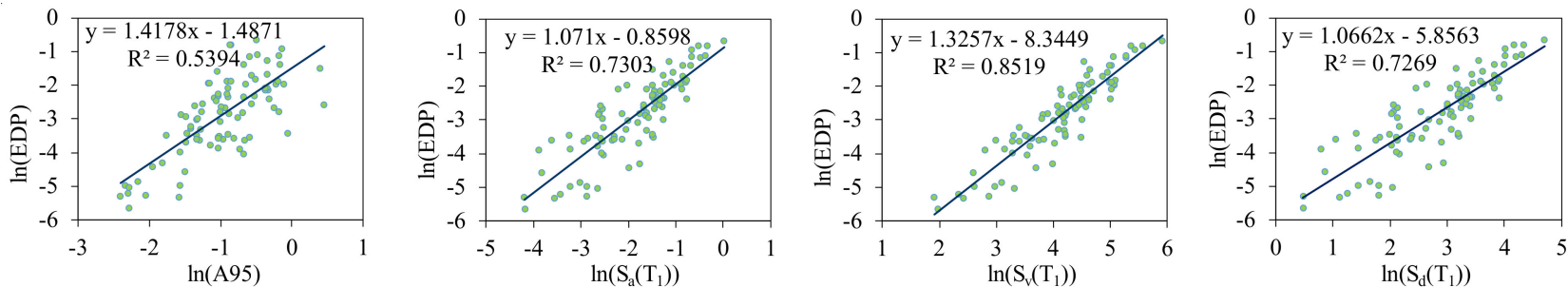

Figure 12. PSDMs with respect to MID of LRB for various IMs.
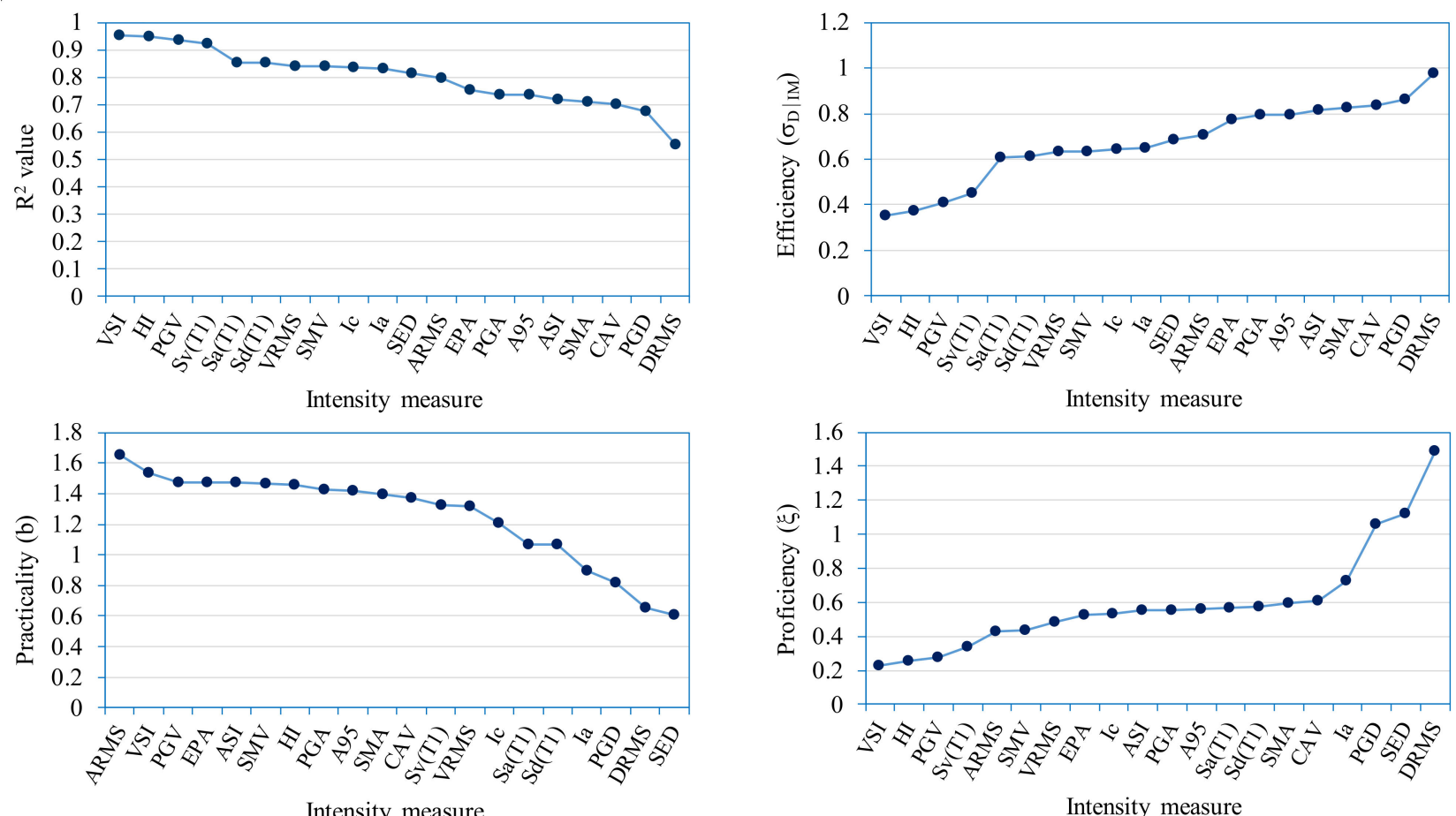

Figure 13. Ranking of indicators of PSDMs with respect to MID for various IMs.

Author Contributions: Conceptualization, D.-D.N. and T.-H.L.; methodology, D.-D.N.; software, D.-D.N.; validation, D.-D.N., V.-T.P. and T.-H.L.; formal analysis, D.-D.N.; investigation, D.-D.N.; resources, D.-D.N. and T.-H.L.; data curation, D.-D.N.; writing-original draft preparation, D.D.N. and V.-T.P.; writing—review and editing, T.-H.L.; visualization, V.-T.P.; supervision, T.-H.L.; project administration, T.-H.L.; funding acquisition, T.-H.L. All authors have read and agreed to the published version of the manuscript.

Funding: This research was funded by the Korea Institute of Energy Technology Evaluation and Planning (KETEP) and the Ministry of Trade, Industry, and Energy (MOTIE) of the Republic of Korea, grant number 20201510100020.

Institutional Review Board Statement: Not applicable.

Informed Consent Statement: Not applicable.

Data Availability Statement: The data in this study are presented in terms of tables and figures. Further requests will be considered by the corresponding author.

Conflicts of Interest: The authors declare no conflict of interest.

\section{References}

1. Cao, V.; Ronagh, H.R. Correlation between seismic parameters of far-fault motions and damage indices of low-rise reinforced concrete frames. Soil Dynam. Earthq. Eng. 2014, 66, 102-112. [CrossRef] 
2. Pejovic, J.R.; Serdar, N.N.; Pejovic, R.R. Optimal intensity measures for probabilistic seismic demand models of RC high-rise buildings. Earthq. Struct. 2017, 13, 221-230.

3. Padgett, J.E.; Nielson, B.G.; DesRoches, R. Selection of optimal intensity measures in probabilistic seismic demand models of highway bridge portfolios. Earthq. Eng. Struct. Dynam. 2008, 37, 711-725. [CrossRef]

4. Zelaschi, C.; Monteiro, R.; Pinho, R. Critical assessment of intensity measures for seismic response of Italian RC bridge portfolios. J. Earthq. Eng. 2019, 23, 980-1000. [CrossRef]

5. Nguyen, D.D.; Azad, M.S.; Choi, B.H.; Lee, T.H. Efficient Earthquake Intensity Measure for Seismic Vulnerability of Integral Abutment Bridges. J. Korean Soc. Hazard Mitig. 2020, 20, 251-260. [CrossRef]

6. Phan, H.N.; Paolacci, F. Efficient intensity measures for probabilistic seismic response analysis of anchored above-ground liquid steel storage tanks. In Proceedings of the Pressure Vessels and Piping Conference, American Society of Mechanical Engineers, Vancouver, BC, Canada, 17-21 July 2016.

7. Nguyen, D.D.; Park, D.; Shamsher, S.; Nguyen, V.Q.; Lee, T.H. Seismic vulnerability assessment of rectangular cut-and-cover subway tunnels. Tunn. Undergr. Space Technol. 2019, 86, 247-261. [CrossRef]

8. Huang, Z.K.; Pitilakis, K.; Argyroudis, S.; Tsinidis, G.; Zhang, D.M. Selection of optimal intensity measures for fragility assessment of circular tunnels in soft soil deposits. Soil Dynam. Earthq. Eng. 2021, 145, 106724. [CrossRef]

9. Armstrong, R.; Kishida, T.; Park, D. Efficiency of ground motion intensity measures with earthquake-induced earth dam deformations. Earthq. Spectra 2018, 37, 5-25. [CrossRef]

10. Shakib, H.; Jahangiri, V. Intensity measures for the assessment of the seismic response of buried steel pipelines. Bull. Earthq. Eng. 2016, 14, 1265-1284. [CrossRef]

11. Mollaioli, F.; Lucchini, A.; Cheng, Y.; Monti, G. Intensity measures for the seismic response prediction of base-isolated buildings. Bull. Earthq. Eng. 2013, 11, 1841-1866. [CrossRef]

12. Yang, C.; Xie, L.; Li, A.; Jia, J.; Zeng, D. Ground motion intensity measures for seismically isolated RC tall buildings. Soil Dynam. Earthq. Eng. 2019, 125, 105727. [CrossRef]

13. Lee, T.-H.; Mosalam, K.M. Probabilistic Seismic Evaluation of Reinforced Concrete Structural Components and Systems; PEER Report 2006/04; Pacific Earthquake Engineering Research Center: Berkeley, CA, USA, 2006.

14. Pnevmatikos, N.G.; Papagiannopoulos, G.A.; Papavasileiou, G.S. Fragility curves for mixed concrete/steel frames subjected to seismic excitation. Soil Dyn. Earthq. Eng. 2019, 116, 709-713. [CrossRef]

15. Pnevmatilos, N.G.; Thomos, G.C. Stochastic structural control under earthquake excitations. Struct. Contr. Health Monit. 2014, 21, 620-633. [CrossRef]

16. Huang, Y.N.; Whittaker, A.S.; Luco, N. A probabilistic seismic risk assessment procedure for nuclear power plants: (I) Methodology. Nucl. Eng. Des. 2011, 241, 3996-4003. [CrossRef]

17. Nguyen, D.D.; Thusa, B.; Park, H.; Azad, M.S.; Lee, T.H. Efficiency of various structural modelling schemes on evaluating seismic performance and fragility of APR1400 containment building. Nucl. Eng. Technol. 2021, 53, 2696-2707. [CrossRef]

18. Tran, T.T.; Cao, A.T.; Nguyen, T.H.X.; Kim, D. Fragility assessment for electric cabinet in nuclear power plant using response surface methodology. Nucl. Eng. Technol. 2019, 51, 894-903. [CrossRef]

19. Cho, S.G.; Joe, Y.H. Seismic fragility analyses of nuclear power plant structures based on the recorded earthquake data in Korea. Nucl. Eng. Des. 2005, 235, 1867-1874. [CrossRef]

20. Choi, I.K.; Choun, Y.S.; Ahn, S.M.; Seo, J.M. Probabilistic seismic risk analysis of CANDU containment structure for near-fault earthquakes. Nucl. Eng. Des. 2008, 238, 1382-1391. [CrossRef]

21. Lee, H.; Ou, Y.C.; Roh, H.; Lee, J.S. Simplified model and seismic response of integrated nuclear containment system based on frequency adaptive lumped-mass stick modeling approach. KSCE J. Civ. Eng. 2015, 19, 1757-1766.

22. Park, J.B.; Park, N.C.; Lee, S.J.; Park, Y.P.; Choi, Y. Seismic analysis of the APR1400 nuclear reactor system using a verified beam element model. Nucl. Eng. Des. 2017, 313, 108-117. [CrossRef]

23. Ali, A.; Hayah, N.A.; Kim, D.; Cho, S.G. Probabilistic seismic assessment of base-isolated NPPs subjected to strong ground motions of Tohoku earthquake. Nucl. Eng. Technol. 2014, 46, 699-706. [CrossRef]

24. Zhou, Z.; Wong, J.; Mahin, S. Potentiality of using vertical and three-dimensional isolation systems in nuclear structures. Nucl. Eng. Technol. 2016, 48, 1237-1251. [CrossRef]

25. Jung, J.W.; Jang, H.W.; Kim, J.H.; Hong, J.W. Effect of second hardening on floor response spectrum of a base-isolated nuclear power plant. Nucl. Eng. Des. 2017, 322, 138-147. [CrossRef]

26. Nguyen, D.D.; Thusa, B.; Lee, T.H. Seismic Fragility of Base-Isolated Nuclear Power Plant Considering Effects of Near-Fault Ground Motions. J. Korean Soc. Hazard Mitig. 2018, 18, 315-321. [CrossRef]

27. Nguyen, D.D.; Thusa, B.; Lee, T.H. Effects of significant duration of ground motions on seismic responses of base-isolated nuclear power plant. J. Earthq. Eng. Soc. Korea 2019, 23, 149-157. [CrossRef]

28. Eem, S.H.; Jung, H.J.; Kim, M.K.; Choi, I.K. Seismic fragility evaluation of isolated NPP containment structure considering soil-structure interaction effect. J. Earthq. Eng. Soc. Korea 2013, 17, 53-59. [CrossRef]

29. Lee, J.H.; Song, J.K. Seismic fragility analysis of seismically isolated nuclear power plant structures using equivalent linear-and bilinear-lead rubber bearing model. J. Earthq. Eng. Soc. Korea 2015, 19, 207-217. [CrossRef]

30. Sarebanha, A.; Mosqueda, G.; Kim, M.K.; Kim, J.H. Seismic response of base isolated nuclear power plants considering impact to moat walls. Nucl. Eng. Des. 2018, 328, 58-72. [CrossRef] 
31. Kim, S.W.; Jeon, B.G.; Hahm, D.G.; Kim, M.K. Seismic fragility evaluation of the base-isolated nuclear power plant piping system using the failure criterion based on stress-strain. Nucl. Eng. Technol. 2019, 51, 561-572. [CrossRef]

32. Li, C.; Zhai, C.; Kunnath, S.; Ji, D. Methodology for selection of the most damaging ground motions for nuclear power plant structures. Soil Dynam. Earthq. Eng. 2019, 116, 345-357. [CrossRef]

33. Nguyen, D.D.; Thusa, B.; Han, T.S.; Lee, T.H. Identifying significant earthquake intensity measures for evaluating seismic damage and fragility of nuclear power plant structures. Nucl. Eng. Technol. 2020, 52, 192-205. [CrossRef]

34. Nguyen, D.D.; Thusa, B.; Azad, M.S.; Tran, V.L.; Lee, T.H. Optimal earthquake intensity measures for probabilistic seismic demand models of ARP1400 reactor containment building. Nucl. Eng. Technol. 2021, in press. [CrossRef]

35. Tran, T.T.; Le, T.M.T.; Nguyen, P.C.; Kim, D.; Pham, T.M.; Salman, K.; Chang, S. Probabilistic seismic demand model and seismic fragility analysis of NPP equipment subjected to high and low-frequency earthquakes. Nucl. Sci. Eng. 2021, in press. [CrossRef]

36. Kramer, S.L. Geotechnical Earthquake Engineering; Prentice Hall. Inc.: Upper Saddle River, NJ, USA, 1996.

37. SeismoSignal-A Computer Program for Signal Processing of Strong-Motion Data. 2017. Available online: http://www. seismosoft.com (accessed on 15 May 2021).

38. Shome, N. Probabilistic Seismic Demand Analysis of Nonlinear Structures. Ph.D. Thesis, Stanford University, Palo Alto, CA, USA, 1999.

39. PEER Ground Motion Database. 2019. Available online: http://peer.berkeley.edu/peer_ground_motion_database (accessed on 17 May 2019).

40. KMA. Korean Meteorological Administration. Available online: http:/ / www.kma.go.kr/eng/index.jsp (accessed on 15 June 2016).

41. NRC. US Nuclear Regulatory Commission 1.60. In Design Response Spectra for Seismic Design of Nuclear Power Plants, 2nd ed.; Regulatory Guide 1.60: Rockville, MD, USA, 2014.

42. Dobry, R.; Idriss, I.M.; Ng, E. Duration characteristics of horizontal components of strong-motion earthquake records. Bull. Seismol. Soc. Am. 1978, 68, 1487-1520.

43. Arias, A. A Measure of Earthquake Intensity. In Seismic Design for Nuclear Power Plants; Hansen, R.J., Ed.; MIT Press: Cambridge MA, USA, 1970; pp. 438-483.

44. Park, Y.J.; Ang, A.H.S.; Wen, Y.K. Seismic damage analysis of reinforced concrete buildings. J. Struct. Eng. 1985, 111, 740-757. [CrossRef]

45. Benjamin, J.R. A Criterion for Determining Exceedance of the Operating Basis Earthquake; Report No. EPRI NP-5930; Electrical Power Research Institute: Palo Alto, CA, USA, 1988.

46. Thun, V. Earthquake Ground Motions for Design and Analysis of Dams. In Proceedings of the Earthquake Engineering and Soil Dynamics II-Recent Advances in Ground-Motion Evaluation, Park City, UT, USA, 27-30 June 1988.

47. Housner, G.W. Spectrum intensities of strong-motion earthquakes. In Proceedings Symposium on Earthquake and Blast Effects on Structures; Earthquake Engineering Research Institute: Los Angeles, CA, USA, 1952.

48. Nuttli, O.W. The Relation of Sustained Maximum Ground Acceleration and Velocity to Earthquake Intensity and Magnitude; US Army Engineer Waterways Experiment Station: Vicksburg, MS, USA, 1979.

49. Shome, N.; Cornell, C.A.; Bazzurro, P.; Carballo, J.E. Earthquakes, records, and nonlinear responses. Earthq. Spectra 1998, 14, 469-500. [CrossRef]

50. Sarma, S.K.; Yang, K.S. An evaluation of strong motion records and a new parameter A95. Earthq. Eng. Struct. Dynam. 1987, 15, 119-132. [CrossRef]

51. SAP2000, version 15; Software for Structural Analysis and Design Program; Computers and Structures Inc: Berkeley, CA, USA, 2013.

52. Lee, E.H.; Kim, J.M.; Joo, K.H.; Kim, H. Evaluation of the soil-structure interaction effect on seismically isolated nuclear power plant structures. J. Earthq. Eng. Soc. Korea 2016, 20, 379-389. [CrossRef]

53. Kim, G.J.; Yang, K.K.; Kim, B.S.; Kim, H.J.; Yun, S.J.; Song, J.K. Seismic response evaluation of seismically isolated nuclear power plant structure subjected to Gyeong-Ju earthquake. J. Earthq. Eng. Soc. Korea 2016, 20, 453-460. [CrossRef]

54. Cho, S.G.; Yun, S.M.; Kim, D.; Hoo, K.J. Analyses of Vertical Seismic Responses of Seismically Isolated Nuclear Power Plant Structures Supported by Lead Rubber Bearings. J. Earthq. Eng. Soc. Korea 2015, 19, 133-143. [CrossRef]

55. An, G.; Kim, M.; Jung, J.W.; Mosqueda, G.; Marquez, J.F. Evaluation of Clearance to Stop Requirements in A Seismically Isolated Nuclear Power Plant. Energies 2020, 13, 6156. [CrossRef]

56. Lee, T.H.; Nguyen, D.D. Seismic vulnerability assessment of a continuous steel box girder bridge considering influence of LRB properties. Sädhanā 2018, 43, 1-15. [CrossRef]

57. Sarebanha, A.; Marquez, J.; Hughes, P.; Mosqueda, G. Considerations for modeling of base isolated nuclear power plants subjected to beyond design basis shaking. Nucl. Eng. Des. 2021, 379, 111236. [CrossRef]

58. Nguyen, D.D.; Nguyen, C.N. Seismic Responses of NPP Structures Considering the Effects of Lead Rubber Bearing. Eng. Technol. Appl. Sci. Res. 2020, 10, 6500-6503. [CrossRef]

59. Kim, J.H.; Kim, M.K.; Choi, I.K. Experimental Study on the Ultimate Limit State of a Lead-Rubber Bearing. In ASME 2016 Pressure Vessels and Piping Conference; American Society of Mechanical Engineers: Vancouver, BC, Canada, 2016.

60. Kim, J.; Kim, M.; Choi, I. Experimental study on seismic behavior of lead-rubber bearing considering bi-directional horizontal input motions. Eng. Struct. 2019, 198, 109529. [CrossRef] 
61. Eem, S.; Hahm, D. Large strain nonlinear model of lead rubber bearings for beyond design basis earthquakes. Nucl. Eng. Technol. 2019, 51, 600-606. [CrossRef]

62. Schellenberg, A.H.; Sarebanha, A.; Schoettler, M.J.; Mosqueda, G.; Benzoni, G.; Mahin, S.A. Hybrid Simulation of Seismic Isolation Systems Applied to an APR-1400 Nuclear Power Plant; Pacific Earthquake Engineering Research Center: Berkeley, CA, USA, 2015.

63. Cornell, C.A.; Jalayer, F.; Hamburger, R.O.; Foutch, D.A. Probabilistic basis for 2000 SAC federal emergency management agency steel moment frame guidelines. J. Struct. Eng. 2002, 128, 526-533. [CrossRef]

64. Rabiee, R.; Chae, Y. Adaptive base isolation system to achieve structural resiliency under both short-and long-period earthquake ground motions. J. Intell. Mater. Sys. Struct. 2019, 30, 16-31. [CrossRef]

65. Reed, J.W.; Kassawara, R.P. A criterion for determining exceedance of the operating basis earthquake. Nucl. Eng. Des. 1990, 123, 387-396. [CrossRef]

66. Stanisz, P.; Oettingen, M.; Cetnar, J. Monte Carlo modeling of Lead-Cooled Fast Reactor in adiabatic equilibrium state. Nucl. Eng. Des. 2016, 301, 341-352. [CrossRef]

67. Kepisty, G.; Stanisz, P.; Cetnar, J. Monte Carlo burnup in HTR system with various TRISO packing. Ann. Nucl. Energy 2016, 92, 419-430. [CrossRef] 